\title{
WITH A BANG, NOT A WHIMPER: \\ PRICKING GERMANY’s 'STOCK MARKET BUBBLE’ IN 1927 \\ AND THE SLIDE INTO DEPRESSION
}

\author{
Hans-Joachim Voth ${ }^{*}$
}

23.1.2001

\begin{abstract}
In May 1927, the German central bank intervened indirectly to reduce lending to equity investors. The crash that followed ended the only stock market boom during Germany's relative stabilization 1924-28. This paper examines the factors that lead to the intervention as well as its consequences. We argue that genuine concern about the 'exuberant' level of the stock market, in addition to worries about an inflow of foreign funds, tipped the scales in favour of intervention. The evidence strongly suggests that the German central bank under Hjalmar Schacht was wrong to be concerned about stockprices - there was no bubble. Also, the Reichsbank was mistaken in its belief that a fall in the market would reduce the importance of shortterm foreign borrowing, and help to ease conditions in the money market. The misguided intervention had important real effects. Investment suffered, helping to tip Germany into depression.
\end{abstract}

JEL classification codes

Keywords
E31, E43, E44, N14, N24

Stock Market, Foreign Lending, Fixed Exchange Rates, Asset Prices, Bubbles, Germany, Monetary Policy.

\footnotetext{
* Economics Department, Universitat Pompeu Fabra, 08005 Barcelona, Spain and Centre for History and Economics, Cambridge CB2 1ST, UK. Email: hjv23@cam.ac.uk.
} 
During November and December 1928, the American economist James W. Angell was conducting fieldwork for his book on the German economy. Visiting more than fifty factories and mines in the process, he came away deeply impressed by the prosperity and dynamism he encountered: "[O]nly six years after her utter collapse, Germany is once again one of the great industrial nations... and she is rapidly increasing her power. ... It is one of the most spectacular recoveries in the world's entire economic history." ${ }^{1}$ From the ashes of hyperinflation, the country had apparently turned itself into one of continental Europe's great success stories. Inflation was low and stable, and the pre-war exchange rate vis-à-vis the dollar had successfully been restored. Employment was rising rapidly, export volumes were surging, and labor productivity was increasing at twice the pre-war rate. ${ }^{2}$

The image of prosperity that captivated Angell was in many ways a final flourish, followed by a rapid downturn that had already begun before his visit. The recovery after the end of hyperinflation in 1924 was briefly interrupted in 1925/26, only to peter out in $1928 .^{3}$ Many leading indicators such as housing starts and machinery orders already started to point downwards from 1927 or $1928 .{ }^{4}$ Revised estimates of national product show that a peak was reached in $1928 .{ }^{5}$ Production would only 'bottom out' in 1931/32, when the depths of the Great Depression had been reached. It is one of the peculiarities of the German Slump that it began not with a sudden, sharp downturn, but with a slow and gradual slide into depression. ${ }^{6}$ Compared with other industrial nations, the upper turning point of the German business cycle came unusually early - British industrial production only began to decline in 1929, France saw a turning point in 1930, and the US in $1929 .^{7}$ Why, then, did Weimar Germany's only boom last for no more than a few years?

The most influential interpretation is that of Knut Borchardt, who argued that Weimar's economy was doomed by high labour costs. The system of state arbitration, he argued, drove

\footnotetext{
1 Angell 1929, p. 2.

${ }^{2}$ Holtfrerich 1984.

${ }^{3}$ In its initial phase, the inflation had numerous positive effects. Cf. Holtfrerich 1986.

${ }^{4}$ Ritschl 1999. Construction peaked in the summer of 1927, and the production of consumer goods reached its high point in February 1928. Industrial production in 1928 was almost exactly as high as in 1929, before contracting sharply. James 1990.

${ }^{5}$ Ritschl 1997, table B1.

${ }^{6}$ Balderston 1993, p. 1-4; James 1986.

${ }^{7}$ Many commodity exporters experienced early downturns during the 1920 s as well, but their troubles were the primarily the results of falling prices for their main export staples. Cf. Temin 1989, p. 2.
} 
unit labour costs up, rendering German goods uncompetitive on world markets. ${ }^{8}$ The export surpluses that should have financed reparations never materialized. Foreign capital had to fill the gap, but left the country exposed in case of a sudden halt to inflows. Investment failed to recover to pre-war levels. In the final analysis, Weimar's economy could not deliver the growth performance that would have ensured political and social stability. The very depth of the crisis after 1929 was a result of these earlier imbalances.

Critics have pointed out numerous problems with this line of reasoning. While real wages and unit labour costs were probably higher than they had been in 1913, they probably failed to harm investment in the way alleged by Borchardt - the consensus view now is that the share of investment in national income during the Weimar years was no lower than before the war. ${ }^{9}$ Also, the spectacular recovery under the Nazis proceeded with wages that were as high or higher than they had been during the 'roaring twenties'. The dominant view now sees the depth and length of the German slump as a result of the way the gold standard operated, and of the failure to cut the link with gold. ${ }^{10}$

If the German economy was not fundamentally 'unhealthy', as Borchardt argued, an alternative explanation for the early onset of the economic crisis needs to be found. The once popular story about a decline in foreign lending to Germany as a result of the Wall Street boom has been thoroughly dismantled by Temin, who demonstrated that the decline in credit occurred too early to be explained by funds being 'syphoned off' to the US. ${ }^{11} \mathrm{He}$ posited 'autonomous' declines in investment spending as the prime cause. In 1928 alone, net investment fell by 15 percent, most of it driven by lower inventory investment. From 1927 to 1929, the fall in investment was 55 percent - more than enough to explain the fall in national product. $^{12}$ Balderston and James, in an attempt to find domestic reasons for the decline, argued that the failure of profitability to revive in 1927/28 soured business sentiment, and that a wave of pessimism undermined plans for additional investment. ${ }^{13}$

\footnotetext{
${ }^{8}$ Borchardt 1991; Ritschl 1990.

${ }^{9}$ Spoerer 1997, Voth 1993. Saving by the government sector partly made up for any reduction in private sector saving. Cf. Holtfrerich 1984.

${ }^{10}$ This is the implication of Eichengreen and Sachs 1985. Whether it was possible to do so or not has been much debated. Cf. Borchardt 1982.

${ }^{11}$ Temin 1971. He has been challenged by Falkus (1973) and Balderston (1977, 1983). Ritschl (1999) confirms Temin's hypothesis on the basis of new data.

${ }^{12}$ Cf. Temin 1976, table 28, p. 156.
} 
This paper is an attempt to take Temin's analysis one step further. An intervention by the Reichsbank brought about the sharp fall in the market, undermining business confidence. I argue that the stock market crash in Berlin on 'Black Friday', May 13th 1927, was also an important factor for the subsequent fall in investment spending. The next section describes the intervention and the motivations behind it. Section III examines the valuation of the German stock market, and section IV analyses the effects of the crash.

\section{THE REICHBANK INTERVENTION}

During the hyperinflation, German stocks had often become extremely cheap. In November 1922, for example, the capitalization of Daimler Motor Works was equivalent to the value of 327 of its cars. ${ }^{14}$ Market volatility was extremely high, with share prices often changing by 30 or even 50 percent per month in real terms. ${ }^{15}$ After the Mark's stabilization in late 1923, stock prices first fell. From the summer of 1924, however, a long bull run began. The economic downturn in 1925/26 did little to sour the mood.

From October 1926 onwards, the Reichsbank began to believe that funds were being diverted from 'productive uses' to the stock market. ${ }^{16}$ It also feared that holdings of gold and foreign exchange could suffer if the substantial gains of foreign investors were repatriated. Schacht decided to lean on the banks to reduce their lending against shares held as collateral. To add emphasis to his policy, banks that failed to comply were threatened with reduced (or even no) rediscount facilities. Banks were highly vulnerable to this kind of threat as the liquidity of their balance sheets was unusually low. ${ }^{17}$ On May 12, the Berlin banks issued a joint statement in which they announced far-reaching measures to curtail lending against securities. The next day became known as 'Black Friday' - prices retreated on a broad front, falling by an average of 11 percent. The impact was felt most severely in the futures market, and then spread to the cash market.

\footnotetext{
13 Balderston 1993, p. 378-81. James 1990, p. 39-41.

${ }^{14}$ Guttmann and Meehan 1975, p. 148.

15 The stock market data is from Gielen (1994), and was kindly made available in electronic form by George Bittlingmayer. Gielen uses a variety of sources to ensure a complete series between 1870 and 1993 . His index is widely recognized as the single best source for long-run data on German stock prices. Cf. Jorion and Goetzmann 1999.

${ }^{16}$ Beer 1999, p. 204-6.

17 Balderston 1993, p. 207-8.
} 
Dividend Yield and Stock Prices in Germany, 1925-30

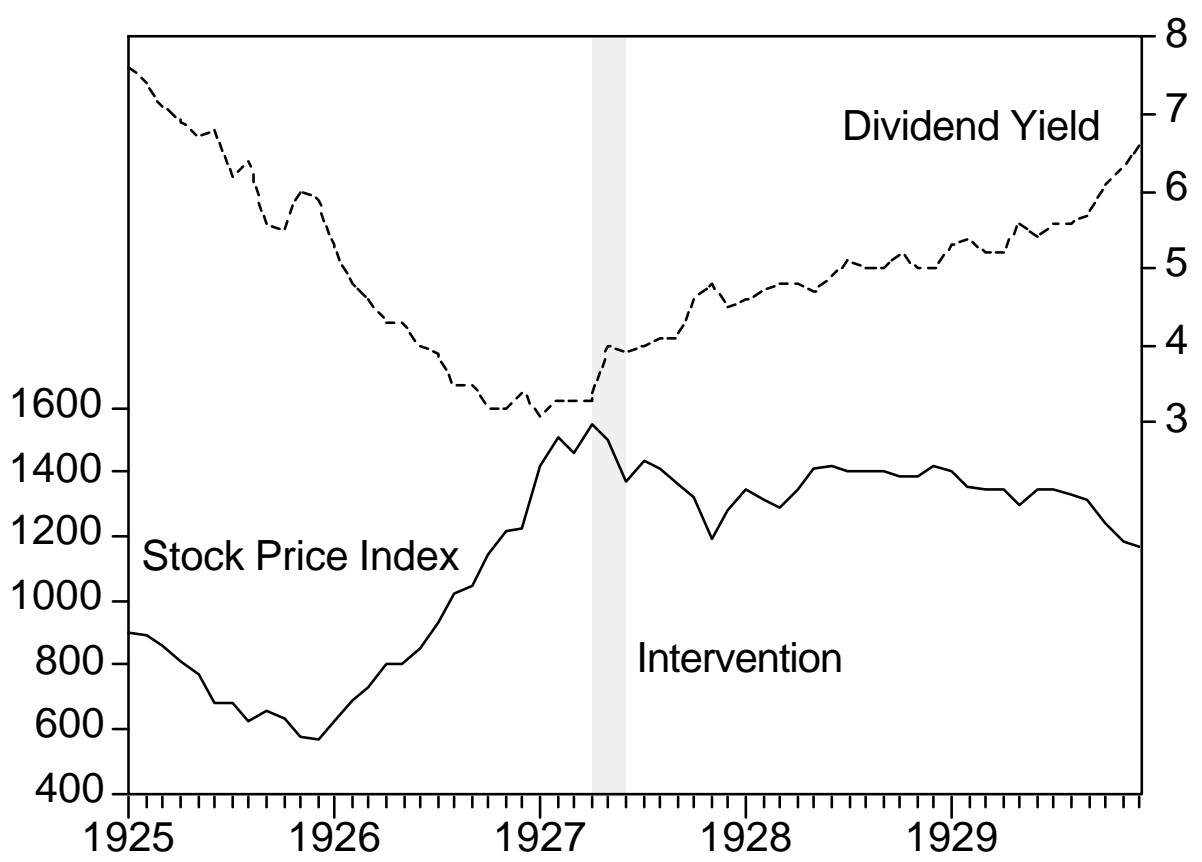

\section{Figure 1}

Harold James has argued that three principal factors were behind the Reichsbank's intervention. First, it felt that speculative excesses had driven up equity prices to unsustainable levels. Second, the stock market was absorbing much-needed funds that would otherwise be available for productive investment in private industry. Third, the strength of German stocks had led to inflows of 'hot money', speculative balances lent principally by American firms that might be withdrawn quickly at the first sign of a downturn. ${ }^{18}$

Much of the literature on Reichbank policy in the late 1920s has focused on the issue of foreign loans and reparations. ${ }^{19}$ The second and third factors cited by James clearly weighted heavily in the minds of Reichsbank officials, Schacht most prominently among them. During 1926, Germany had increasingly attracted inflows of foreign funds, both on a long-term and a short-term basis. German interest rates were still higher than in the US and Britain. With free capital movement under the gold standard, the Reichsbank increasingly lost influence over the money supply (much to its chagrin). Money market rates fell below the official discount rate. This is, of course, exactly what the Mundell-Fleming model would predict with a fixed

\footnotetext{
18 James 1985 , p. 39.

${ }^{19}$ Hardach 1976, p. 73-81; Balderston 1993, p. 207-9; Cf. also Müller 1973. Schuker 1988.
} 
exchange rate and perfect capital mobility - monetary policy becomes largely powerless. In contrast, fiscal policy is all the more effective. If the Reichsbank was not to lose its influence on the German economy altogether, it had to start influencing public borrowing and spending. ${ }^{20}$ There were also strong reasons to worry about the increasing vulnerability of the economy to speculative attack should the inflow of foreign capital come to a sudden halt. ${ }^{21}$ As German domestic savings in the aftermath of the inflation were low, however, considerable foreign borrowing was inevitable. It was therefore through controlling access to foreign capital that Schacht attempted to reassert control over economic policy. ${ }^{22}$

In late 1926, the Reichsbank convinced the government to abolish the preferential tax treatment of bonds floated abroad. Double taxation would now be applied. Simultaneously, the German central bank lowered its discount rate from 6 to 5 percent to reduce the attractiveness to foreign lenders. The policy was more successful than its instigators had anticipated. Long-term foreign loans came to an almost complete standstill, falling from $800 \mathrm{mn}$ RM in the last six months of 1926 to $200 \mathrm{mn}$ RM in the first half of 1927. Combined with reparations transfers, the Reichsbank was losing foreign exchange to the tune of 500mn $\mathrm{RM}$ in the first two months of 1927 alone. ${ }^{23}$ By April, backing for the German currency in terms of foreign exchange and gold had fallen sharply - from some 85 percent of currency in circulation in January 1927 to no more than 65 percent. Since the Dawes Plan stipulated a minimum of 40 percent backing, the Reichsbank needed to act soon. Faced with dwindling reserves, the standard response under gold-standard rules would have been to raise the discount rate again. ${ }^{24}$ Public reaction after the crash noted that such a reversal of its decision in January would probably have dealt the Reichsbank's reputation a considerable blow. ${ }^{25}$

\footnotetext{
20 The Reichsbank also became increasingly concerned that reparations transfers were effectively financed through foreign loans, and not a trade surplus. Cf. Bericht des Reichsbankpräsidenten über währungs- und finanzpolitische Fragen, 7.3.1927, in: Abramowski 1988, p. 599; Hardach 1976, p. 73-4.

${ }^{21}$ The dangers of foreign borrowing in a system of fixed exchange rates have recently been demonstrated by the Asian crisis in 1997-8. Models of speculative attack devised in response are highly instructive for the case of interwar Europe; cf. Krugman 1999b, Flood and Marion 1999.

${ }^{22}$ Of course, the various measures such as the "Beratungsstelle", whose approval for the taking of foreign loans was required, had also reduced the extent of foreign capital mobility. Cf. Hardach 1976, p. 57.

23 Hardach 1976, p. 78.

${ }^{24}$ Since foreign loans were few and far between, and the economic expansion of early 1927 increased the demand for credit from the private sector, the Reichsbank had 're-established contact with the market'. Its discount rate could once again influence interest rates in the money market. Cf. Balderston 1993, p. 150-3.

${ }^{25}$ Frankfurter Zeitung 14.5./15.5.1927.
} 
Instead of raising interest rates, the Reichsbank decided to target the banks responsible for lending to the stock market. It had some evidence to suggest that both directly and indirectly, short-term funds from abroad were used to fund margin lending. Schacht felt that the sudden tightness of credit conditions was partly driven by the stock market boom. Credit that could have been used to fund productive investment was being diverted to the stock market, or so the Reichsbank argued. ${ }^{26}$ Also, by reducing the attractiveness of German assets, capital imports would be less likely. In contrast, a rise in the discount rate would encourage further inflows of short-term funds.

It is in the context of foreign borrowing that the Reichsbank intervention had the least to recommend it - both in the eyes of contemporaries and with hindsight. ${ }^{27}$ The intervention in the stock market blatantly failed to achieve any of its aims in terms of foreign borrowing. Contemporary critics had already pointed out that the stock market does not absorb capital, since all purchases are matched by sales. ${ }^{28}$ Instead of easing conditions in the money market by reducing the 'claims of the stock market', the cut in lending volume simply led to an overall contraction of credit in the economy. ${ }^{29}$ As was only to be expected, this aggravated the tightness in the money market that it was meant to cure. With long-term lending still effectively shut off as a result of the tax changes, short-term inflows increased from $300 \mathrm{mn}$ $\mathrm{RM}$ in the first quarter of 1927 to $1.1 \mathrm{bn} \mathrm{RM}$ in the second - the exact opposite of what Schacht had intended. By trying to reduce the inflow of long-term loans, he had pushed up the scale of short-term borrowing abroad, rendering the German position even more precarious in case of sudden withdrawals. ${ }^{30}$ The decision to raise interest rates on June 10 was tantamount to a public admission that the central aims of the strike against the stock market had not been achieved. $^{31}$

\footnotetext{
${ }^{26}$ In his presentation before the cabinet, Schacht argues that a sudden crash on the bourse would release cash that had been locked up in credits to the Bourse. Cf. Abramowski 1988, p. 608. The Reichsbank later denied having made such claims. Cf. Beer 1999, p. 205.

27 Adolf Weber (1928), in a famous essay entitled "Is Schacht Right?" argued that the Reichsbank president's policy was fundamentally contradictory.

${ }^{28}$ Cf. the series of articles in the Frankfurter Zeitung by Gustav Cassel, Albert Hahn, Alfred Lansburgh, and Arthur Spiethoff (8.5., 9.5., 11.5, and 12.5.).

${ }^{29}$ Benning 1929.

${ }^{30}$ Cf. Temin (1976, table 27, p. 154), who shows short-term lending surging from $9.7 \%$ in 1926 to $51.1 \%$ in 1927.

${ }^{31}$ Cf. Hardach 1976, p. 81. Benning 1929; Weber 1928.
} 
Also, there appears to be little evidence that margin lending was excessive. While the total volume of loans to the stock market did increase rapidly in 1926/27, it was still only approximately half of what it had been in the pre-war period. ${ }^{32}$ This suggests that, contrary to Reichsbank claims, foreign loans did not lead to unprecedented credit expansion on the stock market.

The first factor cited by James in favour of intervention has received much less attention than the other two. This paper argues that critics of the Reichsbank have emphasized aims of the intervention that are easily questioned. The importance of genuine concern about the level of the market in Schacht's thinking has not been uniformly appreciated. ${ }^{33}$ I argue that reducing speculative excesses was an important factor in its own right for the Reichsbank's actions, and not merely a figleaf for intervention against foreign borrowing. On the one hand, the Reichsbank worried about wealth effects pushing up consumption and affecting the balance of trade. In his report to the government, Schacht made scathing remarks about the 'luxury consumption' enjoyed by speculators who had made easy gains on the stock market. ${ }^{34}$ After the intervention, when speaking in the Northern German town of Stralsund, he castigated the harmful consequences of such extravagance. Imports of foreign luxury cars were surging, he alleged, aggravating Germany's balance of trade deficit: ${ }^{35}$ "The money that has been gained easily on the exchange is ... not returned to the economy. I have the impression that it is used in restaurants and inns, it is being consumed, and to a large extent, it is also used to pay for foreign luxury products (such as expensive automobiles). ... For the Reich and the German economy, these foreign luxury imports, paid with capital gains from the stock exchange, are unhealthy and unbearable. This is the only reason why the Reichsbank has intervened."

Despite the firebrand rhetoric, concern about the market's valuation and economic imbalances arising from this were not mere auxiliary arguments in the context of foreign lending. In an internal memorandum, the Reichsbank's economics and statistics division emphasized the importance of wealth effects - additional purchases of consumer goods as a result of higher net worth. In an economy impoverished by war and inflation, such a spending spree - the

\footnotetext{
32 Benning 1929, p. 116.

${ }^{33}$ Harold James is one of the few historians who sees the three factors as approximately equal in importance. Cf. James 1985, p. 39.

34 Bericht des Reichsbankpräsidenten über währungs- und finanzpolitische Fragen, 7.3.1927, in: Abramowski 1988, p. 608, p. 591.

${ }^{35}$ Stralsunder Tageblatt, 27.5.1927.
} 
Reichsbank argued - was entirely understandable. Nonetheless, because of the dangers involved, it was imperative to end excessive speculation. ${ }^{36}$ These worries must be seen in the context of a sharply deteriorating current account in 1927, which added urgency to concerns about a surge of luxury imports. ${ }^{37}$

Schacht also worried about the level of stock prices in its own right. The first reason was that high equity valuations were politically inconvenient. High share prices appeared to indicate that Germany had recovered fully from the war, and that its wealth was rising rapidly. ${ }^{38}$ This was a signal that Schacht, a vociferous opponent of reparations, was not keen to send at a time when renegotiation of Germany's obligations under the Dawes Plan was about to begin:

The artificial rise in equity values, driven by the distortion in the money market, has meant that foreigners - according to my estimates - have gained 500mn RM on the Berlin Bourse... the final result is ... that we suffer from a complete illusion about the effective capital stock in Germany, the nation's economic wealth, and the true rate of capital formation. The whole atmosphere in which a revision of the Dawes Plan was likely has vanished because we in Germany have staged this chimera [of wealth]. ${ }^{39}$

Schacht also felt that stock prices were much too high relative to fundamentals. This assessment was based on a detailled analysis of the dividend yield relative to pre-war levels. The aim, therefore, was not just to restrain future increases in share prices, but to actually lower them. ${ }^{40}$ In his report before the Reich's cabinet on 7.3.1927, the Reichsbank President pointed out that

...speculation is primarily responsible for the extraordinary excesses in terms of equity valuations. ... There are people who claim that, at a time when the money market rate is at $5 \%$, a value of 300 for a share paying a $15 \%$ dividend is not too much...I would not like to enter into a theoretical argument, but would like to point out what the situation in 1913 was like. The yield of fixed securities quoted on the Berlin stock exchange was $4.5 \%$. The [dividend] yield of shares was somewhat lower, $3.97 \%$, since shares offer a speculative upside. The difference in yield between bonds and shares was a mere $0.5 \%$. Today, we see bonds offering a yield of $7.12 \%$, while shares (even if we look at the latest dividend figures) yield $3.44 \%$. That not only means that today's [dividend] yield

\footnotetext{
${ }^{36}$ Nimmt die Börse Kapital in Anspruch? Betrachtungen zu den Ausführungen der FZ, Bericht der VoStA, cit. in Beer 1999, p. 206. Typically, wealth effects are seen as problematic if they lead to overheating, i.e. push the economy's growth rate above the sustainable long-term rate. The Reichsbank argues that additional consumption was problematic at a time when domestic capital formation was too low anyway.

${ }^{37}$ Bundesbank 1976, p. 322.

${ }^{38}$ Beer 1998, p. 201.

39 Bericht des Reichsbankpräsidenten über währungs- und finanzpolitische Fragen, 7.3.1927, in: Abramowski 1988, p. 591.

${ }^{40}$ For a view to the contrary, cf. Balderston 1993, p. 212.
} 
is lower than in 1913, when we [the German people] were richer, but it also means that the difference in yields is more than $3.5 \%$ now... This proves how unhealthy current conditions are; everybody is buying shares because they think there will be future capital gains ... ${ }^{41}$

Relative to the relationship between bond and dividend yields before the war, the Reichsbank felt that the market was grossly overvalued. As the final sentence makes clear, Schacht was concerned about the build-up of a classical bubble, where price increases are simply driven by earlier price rises, the level of the market having lost all contact with fundamentals. ${ }^{42}$ In his Stralsund speech, he actually referred to the conditions in the German equity market as a bubble. ${ }^{43}$ This is why Schacht believed that nothing better could happen to Germany than a crash. ${ }^{44}$ Genuine concern about an overvalued stock market and the fundamental imbalances in the economy it created were important factors for intervention in their own right. ${ }^{45}$

Much of the literature on Reichsbank policy during the 1920s has found fault with the intervention in May 1927 because it did not achieve its professed aims in the money markets and in terms of foreign lending. ${ }^{46}$ Money market conditions did not ease, and the inflow of foreign funds was not curbed. The only possible remaining defence of the Reichsbank's intervention is that there was a speculative bubble in the German stock market, as Schacht forcefully argued, and that pricking it reduced dangerous imbalances in the German economy.

\footnotetext{
${ }^{41}$ Bericht des Reichsbankpräsidenten über währungs- und finanzpolitische Fragen, 7.3.1927, in: Abramowski 1988, p. 590

42 As Charles P. Kindleberger (1987) put it: "A bubble may be defined loosely as a sharp rise the price of an asset ... , with the initial rise generating expectations of further rises and attracting new buyers - generally speculators interested in profits from trading in the asset rather than its use or earning capacity."

${ }^{43}$ Schacht used the term "Börsenblase". Stralsunder Tageblatt, 27.5.1927, p. 2

${ }^{44}$ Schacht said that "... this level of share prices will under all circumstances collapse and that nothing better could happen to us than that it collapses... " Abramowski 1988, p. 608.

${ }^{45}$ Note also the context in which the Reichsbank President discusses the stock market's valuation. Whereas the traditional interpretation sees the stock market as merely one factor aggravating the foreign loan worries of the Reichsbank, the line of argument is reversed here. Schacht argues that abnormal conditions in the money market as a result of foreign loans are leading to excesses in the stock market - which are a cause for worry in their own right.

${ }^{46}$ Benning 1929, 166-72; Hardach 1976, p. 78-81.
} 


\section{WAS THERE A BUBBLE?}

After the market's fall, the sharpness of the correction itself was seen by some as a sign that there was 'irrational exuberance' in the markets before. Schacht argued as much, and some foreign observers agreed. On May 15, two days after 'Black Friday', the New York Times reported Wall Street circles as saying that "the panicky collapse on the Berlin Stock Exchange was universally ascribed to a vastly overextended speculation". ${ }^{47}$ Also, margin requirements for firms trading equities forward were raised rapidly during the boom, from 5 percent in 1925 to 15 percent in $1927 .{ }^{48}$ As Rappoport and White have argued in the case of brokers' loans in the US in 1929, such increases can be seen as a sign that market participants feared a bubble. ${ }^{49}$ Yet there is no universally accepted and foolproof test for the existence of a bubble. ${ }^{50}$ Instead, we need to weigh the evidence from a number of indicators carefully. This section reviews the most important measures and discusses the direction of potential biases. There are four pieces of evidence that imply that there was no systematic overvaluation in the German stock market prior to the Reichsbank's intervention. First, valuations of stocks by any conventional measure do not appear very high. Second, there is no time-series evidence for an asset bubble. Third, the share price increases on the German market are in line with other countries recovering from a traumatic disruption such as the hyperinflation. Finally, a broad range of macroeconomic indicators that are normally affected in the case of a bubble fails to indicate an imbalance.

The market's rebound between December 1925 and April 1927 was spectacular indeed - an increase of 163.8 percent in real terms over a period of 17 months. But a rapid increase in the index alone is clearly insufficient to prove that there was a bubble in the German stock market. Even at the height of the boom - immediately before the Reichsbank's intervention the stock price index was down by half compared to its 1913 level. But since shares simply represent an entitlement to future dividends, any judgement on over- or undervaluation has to take the dividend yield into account - as Schacht did in his presentation to the cabinet in March 1927.

\footnotetext{
${ }^{47}$ New York Times, 15.5.1927.

${ }^{48}$ The 'Liquidationskasse' guaranteed trades in forward shares, but did not act as a central counterparty in Berlin (the main stock exchange at the time). Cf. Veesenmayer 1929, p. 212.

49 Rappoport and White 1993.

${ }^{50}$ The extensive literature on rational bubbles and intrinsic bubbles cannot be reviewed here. For an overview, cf. Froot and Obstfeld 1991.
} 


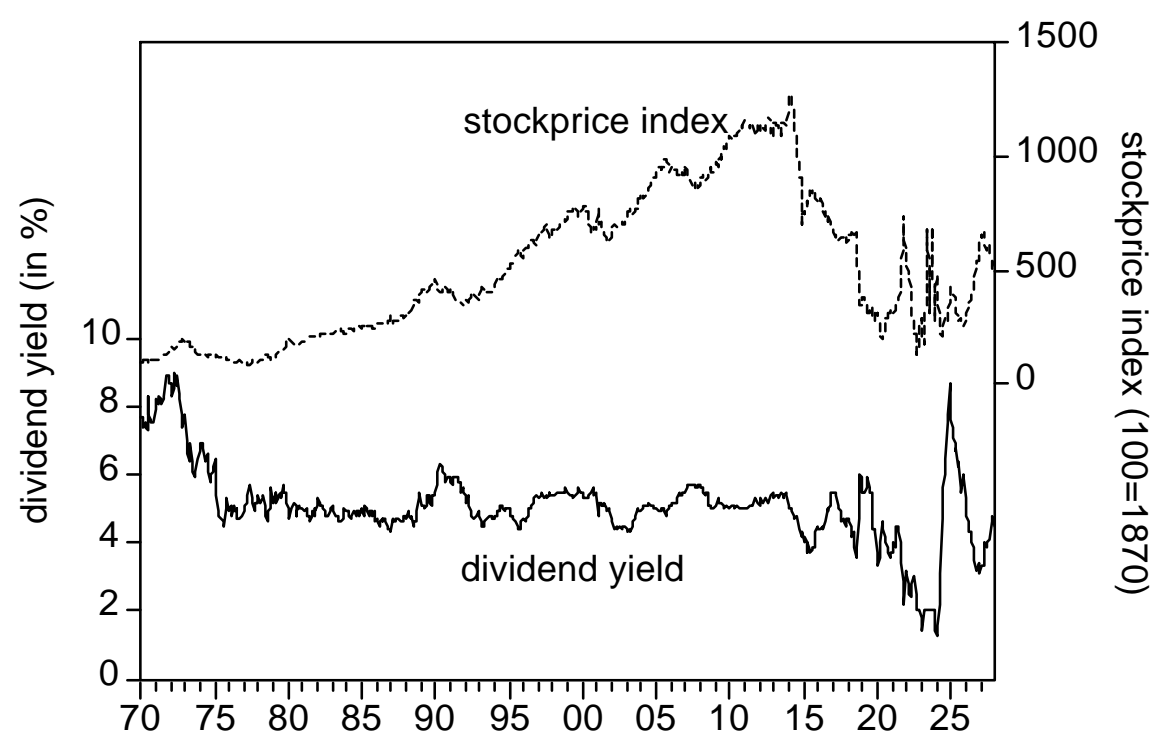

\section{Figure 2}

Figure 2 shows the long-term development of the dividend yield (the ratio of dividends to share prices, in percentage points) and the market index. Over the period 1926/early 1927, the dividend yield declined sharply. During the period Dec. 1925 to April 1927, it averaged a mere 3.8 percent. In January 1927, it reached its lowest value of 3.1 percent. By contrast, the historic long-term average (1870-1913) was 5.4 percent. As Schacht had argued, the level of share prices relative to dividends appeared to be unjustifiably high. However, as the German economy emerged out of the mini-slump in 1926, there were also good reasons to believe that both prices and dividends would continue to rise in the near future. Dividends had declined more than share prices (by 72 percent since 1913), reducing the dividend yield compared to the pre-war standard. By paying a higher price for stocks in terms of the current dividend yield, investors implicitly assumed that dividends would not permanently remain depressed on such a scale. By 1927, according to Maddison, real German GDP per capita was already 10.5 percent higher than in $1913 .{ }^{51}$ Even if wages had risen more than output prices and labour productivity, thus reducing profits, it appears unlikely that the shift in factor shares could be large enough to reduce dividends to such paltry levels permanently.

\footnotetext{
${ }^{51}$ Maddison 1995. The share price index does not adjust for those firms listed in 1913 who were now located on the territory of a foreign state. Total German GDP in 1926 was $2.3 \%$ below the 1913 value (using post-1918 territory). Note that Ritschl (1997) has recently presented detailed evidence suggesting that Maddison's estimates (based on Hoffmann's (1965) data) may be too optimistic.
} 
As rapid subsequent dividend growth makes clear, investors were correct in thinking that fundamentals would eventually recover. The turnaround in prices preceded that in dividends by approximately six months. The rapid rise of dividends throughout the 1920s appears to justify the gains in the stock market (Figure 3).

Stock Price and Dividends, 1925-1930

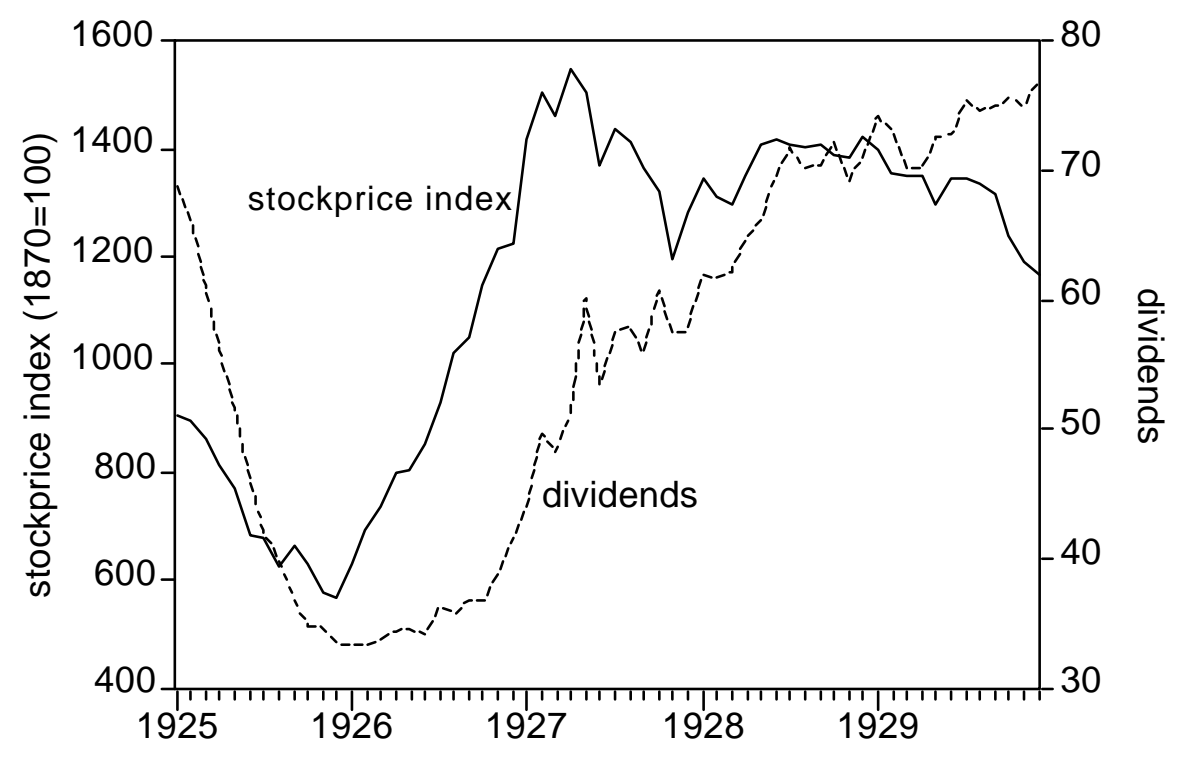

Figure 3

To judge if future dividend growth explains the German bull market in 1926/27, we need a model of share prices. Investing in an equity with a dividend yield below the rate of return on riskless assets will be rational if investors anticipate (sufficiently large) price increases in the future. Ultimately, these must be underpinned by the company's ability to generate cash. The extent to which future dividend increases should be discounted depends on the appropriate interest rate. Gordon presents a model that can be used to calculate implied rates of dividend growth. ${ }^{52}$ In the simplest case, with constant dividend payments, the price of a share should simply be equivalent to the discounted value of future dividend payments:

$$
P=\sum_{t=1}^{N} \frac{D}{(1+R)^{t}}
$$

\footnotetext{
${ }^{52}$ Gordon 1962.
} 
where $\mathrm{P}$ is the price of a share, $\mathrm{D}$ is the dividend payment, $\mathrm{R}$ is the discount rate, and $\mathrm{N}$ is the number of years for which the firm is expected to survive. ${ }^{53}$ If dividends grow at $g$ percent p.a., then the calculation simplifies to

$$
P=\frac{D_{0}(1+g)}{R-g}
$$

Since $\mathrm{D}_{0}$ and $\mathrm{P}$ are observed, we can calculate the implied growth rate of dividends subject to $\mathrm{R}:$

$$
g=\frac{P R-D}{D+P}
$$

The difficulty is in choosing the appropriate rate at which future dividends should be discounted. The following figure gives implied rates of dividend growth for German shares for three alternative values of $\mathrm{R}$ - the monthly interest rate plus a risk premium of 3 percent, the interest rate on mortgage bonds with a gold clause (plus the 3 percent premium), and an assumed rate of return of 10 percent. $^{54}$

\footnotetext{
${ }^{53}$ Note that the discounted value of the firm in its final year is set to zero.

${ }^{54}$ A risk premium of 3 percent appears to be an upper bound on the appropriate rate - the long term real return on German equity (over the period 1924-1991) was 1.91 percent. Cf. Jorion and Goetzmann (1999), table 1, p. 964.
} 


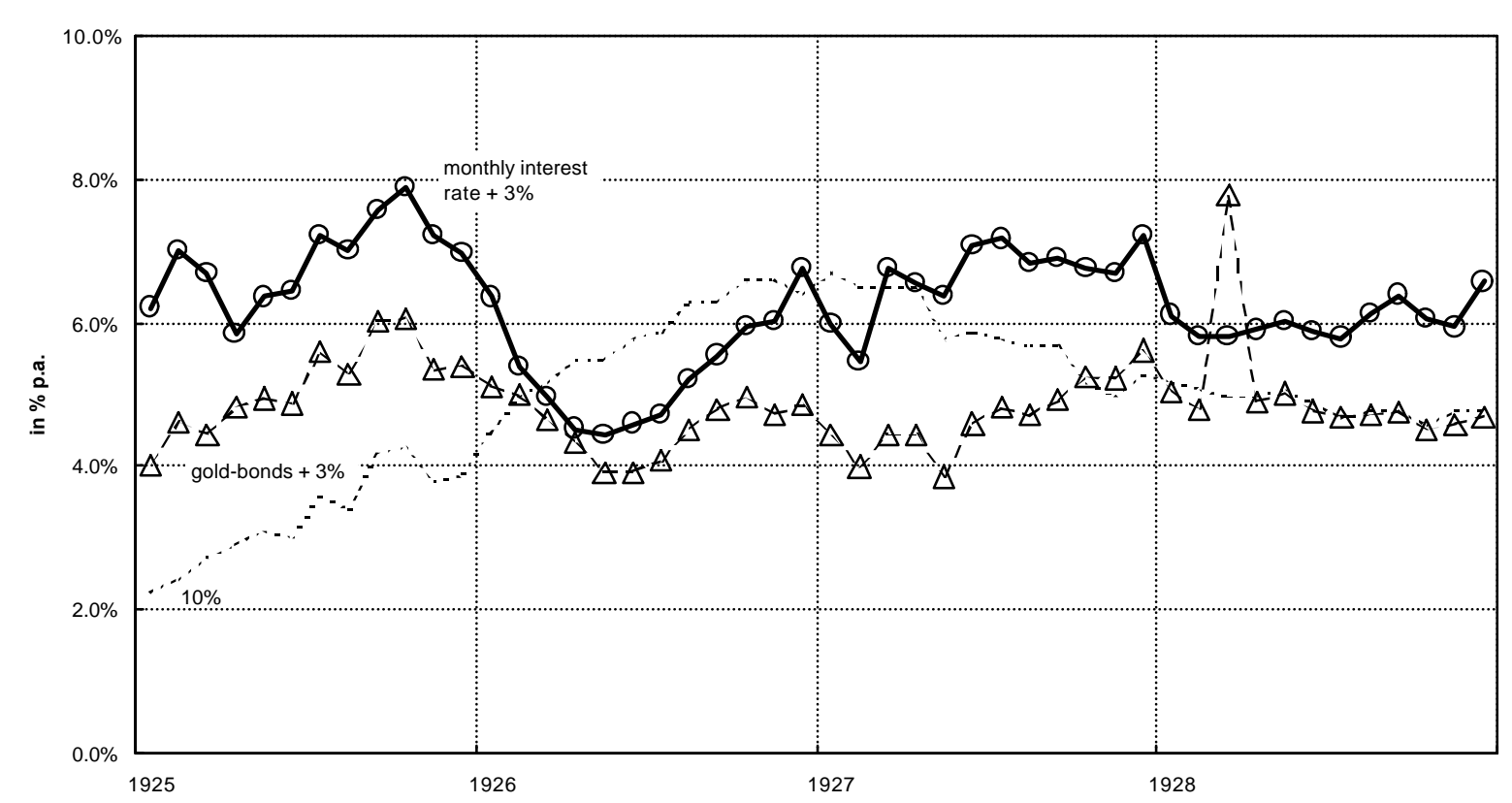

\section{Figure 4}

The implied rates of dividend growth derived from the interest rate market are essentially flat over the period. Using the return on goldbonds plus the 3 percent risk premium, the implied growth rate rises to six percent in the later months of 1925. It then falls during most of the bull-run, and stands at less than 4.5 percent before the Reichsbank intervened. The implied dividend growth rates from monthly interest rates are consistently higher, but show a broadly similar pattern over time. When we use a constant discount rate of 10 percent, however, the implied dividend growth rate increases from approximately 2 percent to over 6 percent in the final phase of the bull run, only to settle down to below 5 percent in the final months of 1928 .

The three alternative discount rates in Figure 4 show significantly different trends over time. The reason for this divergence is that interest rates came down sharply. Monthly interest rates fell from 11.92 percent in February of 1925 to 5.77 percent in June 1926. The yield on mortgage bonds with gold clauses declined from 8.81 percent in November 1925 to 6.07 percent in February of 1927. That equity prices should react strongly to changes in interest rates is no surprise - Shiller's seminal contribution in 1982 has sparked a whole literature demonstrating that most of the variation in share prices cannot be explained by subsequent 
changes in dividends. ${ }^{55}$ Instead, it is changes in the discount factor that appear to be driving much of the variance.

Table 1: Implied Rates of Dividend Growth

\begin{tabular}{lccc}
\hline discount rate & $\begin{array}{c}\text { monthly interest }+ \\
3 \%\end{array}$ & $\begin{array}{c}\text { interest rate on gold- } \\
\text { backed mortgage bonds } \\
+3 \%\end{array}$ & $\begin{array}{c}\text { fixed } \\
(=10.0 \%)\end{array}$ \\
\cline { 2 - 4 } value in 1-25 & $6.2 \%$ & $4.0 \%$ & $2.2 \%$ \\
average 1-25/12-25 & $6.9 \%$ & $5.1 \%$ & $3.3 \%$ \\
average 1-25/4-27 & $6.1 \%$ & $4.8 \%$ & $4.8 \%$ \\
average 4-26/4-27 & $5.6 \%$ & $4.4 \%$ & $6.2 \%$ \\
highest value & $7.9 \%$ & $6.1 \%$ & $6.7 \%$ \\
& $(10-25)$ & $(10-25)$ & $(1-27)$ \\
value in April 27 & $6.6 \%$ & $4.4 \%$ & $6.5 \%$ \\
\hline
\end{tabular}

During the period when a bubble was allegedly developing, the average implied rates of dividend growth did not change much. If the monthly interest rate plus a risk premium is used, the necessary rate of dividend growth to justify the level of share valuations rose from 6.2 percent in January 1925 to 6.6 percent in April 1927, immediately before the intervention. The highest value - indicating the greatest divergence from fundamentals - had been reached in October 1925. The story is similar when we use yields on gold-backed mortgage bonds. Here, the rate rose from 4.0 to 4.4 percent. The peak had also been reached much earlier, in October 1925 . How realistic was a rate of dividend growth of 4.4 to 6.6 percent? ${ }^{56}$

Before World War I, the implied rate of dividend growth had been 1.81 percent (18701913). ${ }^{57}$ This seems to suggest that the German market was indeed overvalued when the Reichsbank decided to strike. Yet before WWI, dividends had actually grown at a rate of 4.5 percent p.a. ${ }^{58}$ Between 1925 and 1927, investors were therefore only betting on rates of dividend growth that were in the same range as those seen during the pre-war era. More importantly, Weimar Germany's economy delivered even higher rates of dividend growth. In the years after the intervention to prick the 'bubble', and into the first year of the Great Depression, dividends continued to grow at a healthy rate of 6.3 percent (4/1927-12/1930).

\footnotetext{
${ }^{55}$ Shiller 1982. Note that DeLong and Becht (1992) found no evidence of "excess volatility" in German share prices prior to WWI. Bittlingmayer (1998) argues that political events are responsible for an important part of total stock price volatility, especially in the interwar period.

${ }^{56}$ Using the highest and the lowest values in Table 1 for April 1927.

57 The rate for the period 1910-13 is almost identical. The interest rate used is the average bond yield. Cf. Bundesbank 1976, table F - 2.01, p. 278.

${ }^{58}$ The real rate of increase was $4.08 \%$.
} 
Not even the constant discount rate of 10 percent, nor the monthly interest rate plus a 3 percent premium, gives implicit rates of dividend growth that are significantly higher than this. The sharp fall in dividends seen in 1931/32 was arguably driven by the unique nature of the Great Slump, and was not a result of a cyclical downturn that rational investors should have anticipated in 1926/27. ${ }^{59}$

Despite the spectacular rise in stock prices, implied dividend growth was only somewhat higher before the intervention than in 1925. This is because the very high interest rates after the stabilisation of the Mark gradually came down. It is only when we derive implicit rates of dividend growth with a fixed interest rate that share valuations are beginning to look increasingly stretched. Yet even for the estimates in the final column of Table 1, the highest point was long past when the Reichsbank decided to strike. The rationality of valuations therefore hinges on the question if it was sensible to expect lower interest rates to persist - i.e. the use of a variable interest rate in the Gordon model instead of a fixed one. The relatively low implicit rates of dividend growth are partly a result of lower interest rates. However, interest rates were still markedly higher than they had been before the war. Expectations of a return to pre-war conditions would argue in favour of using even lower interest rates (reducing the implicit rates of dividend growth). Nor were markets far off the mark in thinking that market conditions would remain broadly constant - the monthly interest rate, at 7.07 percent in April 1927, showed an average of 7.78 percent for the period 1928/30.

Interest rates was not artificially low as a result of an inflow of foreign capital. ${ }^{60}$ Instead, the normalisation of conditions in German money and capital markets was primarily responsible

\footnotetext{
59 The extent to which Weimar's economy was already doomed in the second half of the 1920s has been hotly discussed by Borchardt (1991), Holtfrerich (1990), Ritschl (1997), and Voth (1995). Balderston (1982) provides evidence that wages were indeed out of line with productivity (by the standards of 1913), but that this is not necessarily a sign of Weimar's economy being destined for collapse.

${ }^{60}$ It is possible to argue that there was a vicious cycle that could have driven a self-sustaining bubble in the German stock market. Under this story, inflows of foreign funds lowered interest rates and pumped up valuations of German equities, both as a result of added margin lending and the change in the discount factor. The high returns on German assets would then lead to further capital inflows, producing explosive behaviour of both foreign liabilities and share prices. There is one crucial underlying assumptions - that capital inflows lowered interest rates. The empirical evidence does not support such a connection. While the money market rate was mildly (and insignificantly) negatively correlated with short- and long-term capital inflows ( $\mathrm{r}=-0.25$ and -0.35 , respectively), the yield on gold bonds is either positively correlated or close to zero ( $\mathrm{r}=0.6$ and -0.01 ). As Temin (1976, p. 156) argued, the link between domestic credit and foreign loans was not as close as some observers believed.
} 
for the decline in rates, but not yet complete. ${ }^{61}$ After the end of the hyperinflation, trust in the currency gradually returned, reducing risk premia and inflationary expectations. Figure 5 plots the interest rate for daily money alongside the yield on gold-backed mortgage bonds. ${ }^{62}$ While the mortgage bonds offered some protection against a recurrence of inflation, daily money did not. The difference between the two - abstracting from the difference in maturity, which will have had only a relatively small influence - is an indicator of inflationary expectations. ${ }^{63}$ The figure demonstrates the extent to which the overall fall in interest rates is a result of normalisation in the German economy after 1925. Normalisation was also notable in terms of volatility. The extreme swings seen during the period 1919-23 - often apparently related to political events - were now largely a thing of the past. ${ }^{64}$ Since investors needed to be compensated less for volatility, valuations could also be higher.

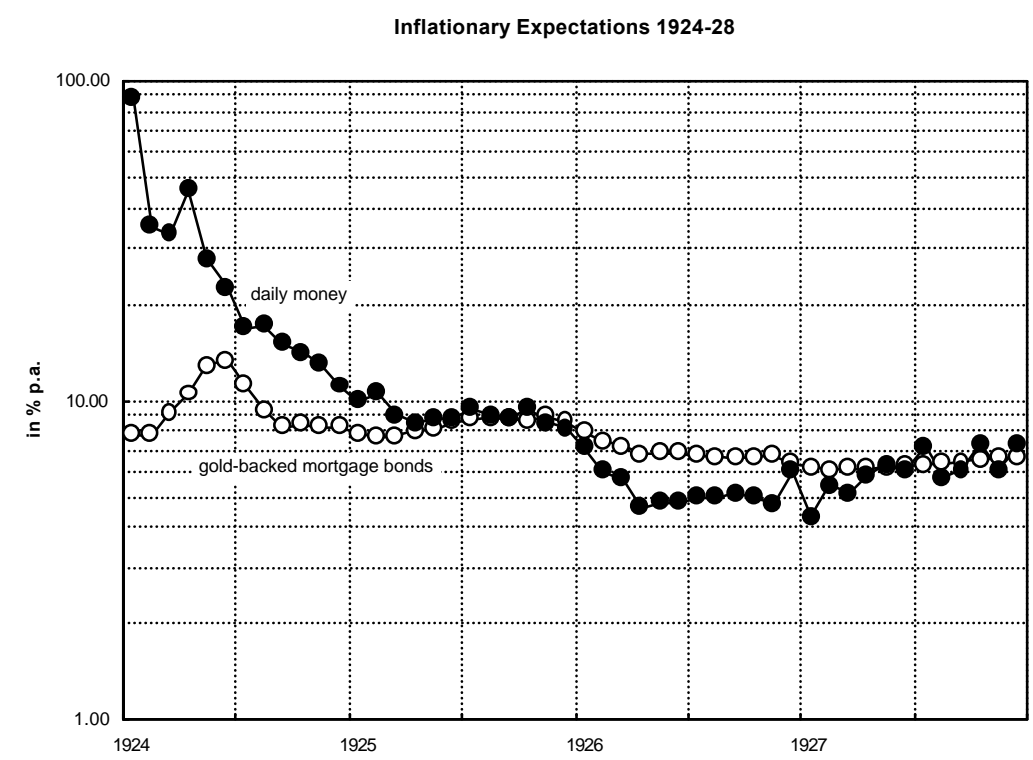

\section{Figure 5}

Standard yardsticks such as the dividend yield therefore do not suggest that the German equity market was rapidly becoming overvalued in 1926 and early 1927. We can strengthen this result by analysing the time-series properties of our data. Hamilton and Whiteman have argued that the existence of a bubble is hard to prove conclusively - test results may simply

\footnotetext{
${ }^{61}$ Most observers note that German interest rates remained unusually high compared to the pre-1913 period as well as in an international perspective. Cf. Holtfrerich 1990.

${ }^{62}$ Institut für Konjunkturforschung 1936.

${ }^{63}$ For an earlier application of the same approach, cf.

${ }^{64}$ Bittlingmayer 1998.
} 
be driven by an inappropriately-specified model. ${ }^{65}$ In particular, tests will be prone to show the existence of a bubble where there was none - investors may be examining fundamentals that the econometrician cannot observe. By using these tests, we stack the odds against our hypothesis that there was no bubble in the German stock market. ${ }^{66}$

Diba and Grossman introduced a bubble test that examines the stationarity of equity returns. They argue that, in the case of a rational bubble, first differences of share prices will be nonstationary. ${ }^{67}$ For the period when 'bubble trouble' was allegedly building rapidly, we can clearly reject the null hypothesis of non-stationarity based on the augmented Dickey-Fuller and the Philipps-Peron test statistics (Table 2). ${ }^{68}$

Table 2: Unit Root Tests - Stock Market Returns

\begin{tabular}{rcccc}
$\begin{array}{c}\text { sample } \\
\text { period }\end{array}$ & $1925: 12-1927: 04$ & $1926: 01-1927: 04$ & $1926: 02-1927: 04$ & $1925: 12-1927: 05$ \\
\cline { 3 - 5 } & & & & \\
ADF & $-4.4^{* *}$ & $-6.04^{* *}$ & $-4.3^{* *}$ & $-3.7^{*}$ \\
PP & $-5.1^{* *}$ & $-5.3^{* *}$ & $-4.5^{* *}$ & $-4.3^{* *}$ \\
DW & 2.4 & 2.2 & 2.2 & 2.1 \\
\hline
\end{tabular}

** indicates significance at the $1 \%$ level

* indicates significance at the $5 \%$ level

An alternative approach is to examine the time-series properties of share prices. Shiller and Campbell suggest to test if share prices and dividends are $I(1)$ and cointegrated; if they are, there is little reason to suspect that there is a bubble building up. ${ }^{69}$ The Johansen test allows us to test for the number of cointegrating vectors. If there is one cointegrating vector for two variables, then they are cointegrated. If the null of no vector cannot be rejected, or there are as many vectors as there are variables, then there is no evidence of cointegration. Table 3 gives the results for using the Johansen procedure for the dividend and share price series. ${ }^{70}$

\footnotetext{
${ }^{65}$ Hamilton 1987, Hamilton and Whiteman 1985.

${ }^{66}$ Note also that most tests of non-stationarity have relatively low power, i.e. they are likely to be unable to reject the null of non-stationarity if it should be. This reinforces the bias against our hypothesis. Cf. Campbell and Perron 1991.

${ }^{67}$ Diba and Grossman 1988.

${ }^{68}$ For the Philipps-Perron test, I used the Newey-West truncation at 2 lags. The DW statistic shows that the lag length is sufficient to ensure that the residuals are free from serial correlations.

${ }^{69}$ Campbell and Shiller 1987. Rappoport and White (1993) apply this procedure to the American stockmarket in 1929 , and find no evidence of a bubble based on this test. Note, however, that they find that their bubble term derived from a model of the brokers' loan market - also is cointegrated with dividends and stock prices.

${ }^{70}$ Pretesting showed conclusively that there was no trend in the data; we also assumed no trend in the data generating process. Objections might be raised because we use cointegration techniques on a relatively brief
} 
Table 3: Johansen Test for Cointegration - Dividends and Share price

\begin{tabular}{|c|c|c|c|c|c|}
\hline & Eigenvalue & $\begin{array}{l}\text { Likelihood } \\
\text { ratio }\end{array}$ & $\begin{array}{l}5 \% \text { critical } \\
\text { value }\end{array}$ & $\begin{array}{l}1 \% \text { critical } \\
\text { value }\end{array}$ & $\begin{array}{c}\text { Hypothesis: } \\
\text { No of co } \\
\text { vectors }\end{array}$ \\
\hline \multirow[t]{2}{*}{ 1/1925-9/1935 } & 0.132 & 18.3 & 12.53 & 16.31 & $0^{*}$ \\
\hline & 0.000003 & 0.0036 & 3.84 & 6.51 & 1 \\
\hline \multirow[t]{2}{*}{$1 / 1925-12 / 1929$} & 0.28 & 19.75 & 12.53 & 16.31 & $0^{*}$ \\
\hline & 0.002 & 0.17 & 3.84 & 6.51 & 1 \\
\hline \multirow[t]{2}{*}{$1 / 1925-12 / 1928$} & 0.38 & 23.3 & 12.53 & 16.31 & $0^{*}$ \\
\hline & 0.005 & 0.24 & 3.84 & 6.51 & 1 \\
\hline
\end{tabular}

Note: * indicates significance at the $5 \%$ level

For most sample periods covering the 'bubble', there is clear evidence from the Johansen cointegration test that dividends and share prices are cointegrated - and that there is therefore no reason to suspect that rapid price increases were fundamentally irrational. However, if we restrict the sample period to the brief period when price increases were most rapid - January 1926 to April 1927 - the cointegrating relationship between share prices and dividends is no longer apparent in the data. ${ }^{71}$ This could be seen as evidence in favour of a bubble. However, simple estimation of cointegrating vectors using two variables ignores the fundamental importance of the discount factor, as demonstrated by Shiller. If we include the interest rate on mortgage-backed bonds in our estimation procedure, the results clearly indicate the presence of one cointegrating vector. ${ }^{72}$ As the Gordon model suggested, some of the market's rapid rise in 1926-7 may have been driven by equities becoming more attractive vis-à-vis bonds.

The time-series properties of the dividend yield have also been used as a test for existence of bubbles in stock markets. ${ }^{73} \mathrm{~A}$ unit root in the price-dividend ratio violates the no-bubble assumption. Testing for unit roots in the price-dividend ratio during the bubble period January 1926 to April 1927 - using both the augmented Dickey-Fuller and the Phillips-Perron

period. Note, however, that recent work by Choi and Chung (1995) and Hooker (1992) suggests that higher frequency may compensate for reductions in sample length.

71 The Johansen test rejects the presence of a maximum of only one integrating vector, i.e. no cointegration either. Note that the period is extremely short for cointegration analysis, which by its very nature is a long-term concept.

${ }^{72}$ We reject the hypothesis of no cointegrating vector at with a likelhood ratio statistic of 49.3 (95\% critical value $=34.9)$, but cannot reject the presence of at most one vector (18.6 vs. a 95\% critical value of 19.96).

${ }^{73}$ Craine 1993. 
technique allows us to reject the null of non-stationarity. ${ }^{74}$ This suggests that our failure to find cointegration between dividends and share prices during the 'bubble' period may be a result of the low power of the tests in a restricted sample.

How do we square the very high equity returns in Germany with the absence of a bubble? International evidence suggests that such a combination of factors is not unusual. Clearly, an economy recovering from hyperinflation is in an special situation. So is its stock market. Poor stock returns during inflationary periods have been observed in almost all countries. ${ }^{75}$ Once countries stabilize, their markets 're-emerge'. ${ }^{76}$ Unusually high returns are often associated with this return to normalcy - as they are with recovery from other traumatic events such as war. ${ }^{77}$ Table 4 gives descriptive statistics for 5 equity markets after very high rates of inflation had been brought under control, and compares these figures with the results for Germany during Weimar's only boom. ${ }^{78}$ In each of the five cases, inflation rates were very high running at more than $100 \%$ p.a. - but none of them can compare with the extreme rates seen during the final phase of Germany's hyperinflation. Since higher returns follow more extreme episodes of inflation, the difference in experience between our "control" sample and Germany biases our result against finding low or normal gains in the German case. ${ }^{79}$

\footnotetext{
${ }^{74}$ The PP statistic is -5.6 vs. a $1 \%$ critical value of -3.9 , whereas the ADF statistic is -5.2 vs. a $1 \%$ critical value of -3.9 .

${ }^{75}$ Fama and Schwert (1977), Beaulieu (1995).

76 The countries classified as re-emerging in table 3 are recovering from a range of events that caused a temporary halt to market activity or an extreme fall in valuations. Cf. Goetzman and Jorion 1996.

${ }^{77}$ Henry (2000) finds that successful stabilization programs are significantly associated with large increases in stock market values. The rise in the market is larger if inflation was particularly high.

${ }^{78}$ The information in column 1, table 2 is from Goetzmann and Jorion (1999b).

${ }^{79}$ Henry 2000. Note also that the returns in Table 4 for the control sample are derived from price indices, whereas the German figures use the performance index. Since the latter includes re-invested dividends, we further stack the odds against finding German returns that are lower than typical ones.
} 
Table 4: Monthly returns (in \%) and volatility

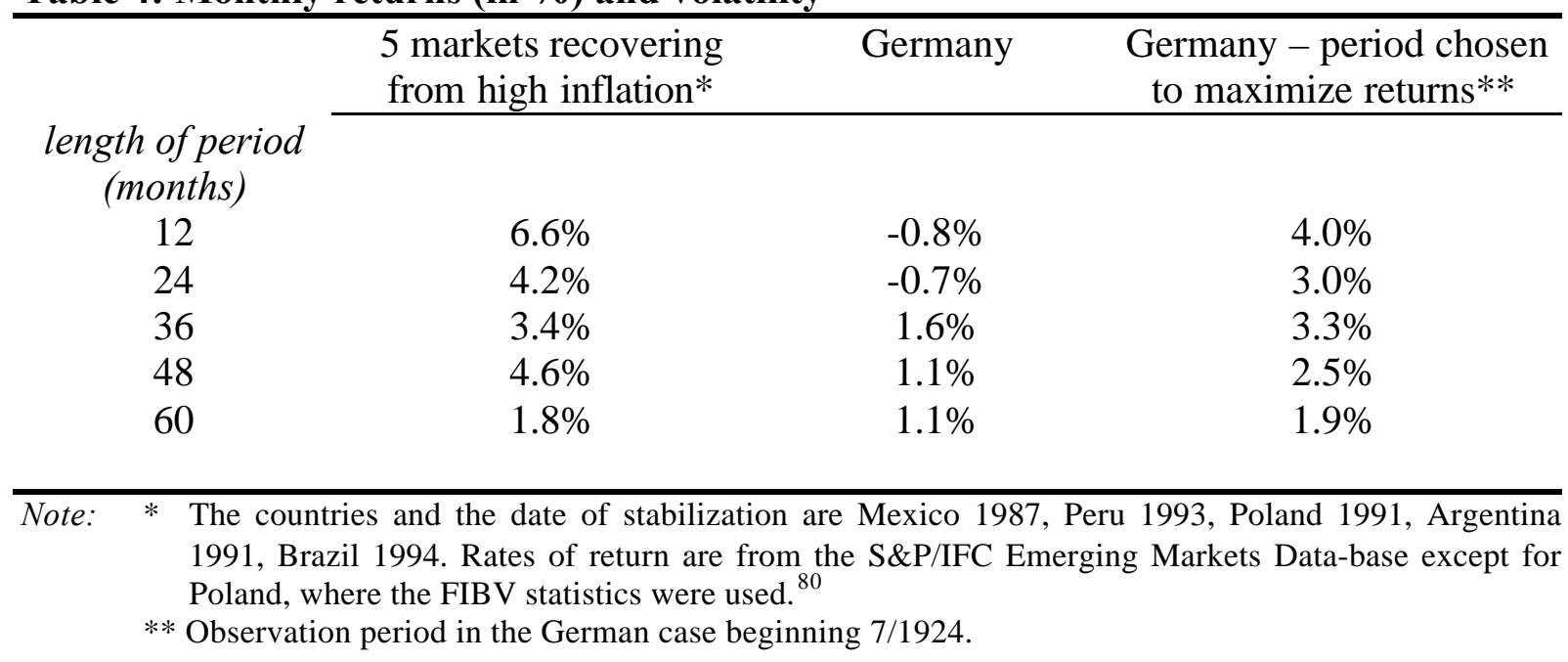

For every time period chosen, post-stabilization returns in Germany are lower than they were in our sample of countries recovering from extreme inflation. They are also lower in each period than any return in any one individual country in the "control" sample. Average returns are highly sensitive to the periods used. We therefore choose the German sample periods so as to maximize the return, increasing the likelihood of finding spectacular gains in the German stock market compared to other countries. For all observation windows, a starting date of July 24 was found to serve the purpose. In this way, we are biasing our results in favour of finding dangerously and 'exuberantly' rapid equity price appreciation in post-inflationary Germany. Nonetheless, German monthly returns are below the average observed in other countries that saw a period of normalization in their stock markets. The only exception is the average return over 60 months following stabilization, when the German return is $0.1 \%$ higher. Again, judged against the background of other stock markets recovering from similar blows, the German market shows no signs of irrational exuberance.

Finally, we can examine the macroeconomic environment. Bubbles normally do not descend on economies out of the blue; a number of authors have argued that they are systematically related to other imbalances in the economy. ${ }^{81}$ Past episodes suggest that five main variables can be examined. The majority of bubbles have been associated with unusually high growth, unusually low inflation, a deteriorating current account, a rapid rise in the money supply as well as falling savings rates. On the bubble checklist compiled by King, the canonical cases

\footnotetext{
${ }^{80} \mathrm{~S} \& \mathrm{P} / \mathrm{IFC}$ indices are from Datastream. The FIBV statistics are available at http://www.fibv.org. Since the latter are only available on an annual basis, the year immediately after stabilization was used.

${ }^{81}$ King 1999.
} 
score high - the Japanese and UK bubbles of the late 1980s, Mexico in the early 1990s, and the current US. Germany in the 1920s, in contrast, only shows some of the familiar signs of a bubble building up. Growth of close to ten percent in 1927 and a relatively rapid deterioration of the current account are the only features of the macroeconomic picture that fully fits the bill. ${ }^{82}$ Inflation is below trend, but rising relatively quickly towards the end of the period - not a perfect parallel with the unusual degree of stability seen in the US or Japan. On all other scores, interwar Germany does not show the normal signs of an economy heading towards excessive asset inflation. To this we might add the observation that most other major asset bubble episodes saw 'spillovers' from the stock market into the real estate market - such as in Britain and Japan in the 1980s. Central banks have all the more reason to worry about wealth effects if property values surge, as most households hold much more equity in their homes than they invest in the stock market. Germany saw no significant increases in real estate prices, let alone a 'bubble' ${ }^{83}$ The balance of evidence - from the absolute level of the stock market to valuation measures, time series properties and typical accompanying factors therefore strongly suggests that there was no bubble in the German stock market.

\section{THE CONSEQUENCES OF THE CRASH}

The preceding section argued that there was little reason for Schacht's attempt to bring down the equity market. The next question we need to address is if the central-bank's intervention and the turmoil it induced in the stock market had significant real effects. Some contemporaries feared that the Reichsbank's intervention would wreak havoc in the economy. The Berlin correspondent for Associated Press reported that

"[i]ndustrial leaders declare that the restriction of bank credits not only will affect share prices adversely but also will handicap the industrial life of the country. It is pointed out that the reorganisation of Germany's industries has not been finished and can be carried out successfully only if the Bourse is able to absorb the new shares which Germany's industries will be obliged to market." 84

The fear was therefore that equity offerings would dry up as the market weakened. The literature's view about 'Black Friday's' consequences is contradictory. While Hardach maintains that the crash had severe consequences, Ritschl has argued that it was of little

\footnotetext{
${ }^{82}$ Bundesbank 1976, p. 322.

${ }^{83}$ The author would like to thank an anonymous referee for this observation.
} 
consequence. ${ }^{85}$ Balderston concluded that weakness in both the bond and the equity market were responsible for the early start of the depression in Germany. ${ }^{86} \mathrm{We}$ find that the slump in equity prices had important real effects, and that investment was lower than it would have been otherwise, had it not been for the intervention by the Reichsbank. It is in this sense that 'Black Friday' contributed to the early onset of the German Slump.

In the case of the US depression after the crash of 1929, analysis of the transmission mechanism has focused on declines in consumption. Contemporaries did not anticipate a fall in business activity as a direct result of the crash. ${ }^{87}$ Also, wealth effects - reductions in consumer spending as a result of lower net household wealth - appear to have been very small. ${ }^{88}$ However, the crash may have weakened household balance sheets, and uncertainty over future income may have caused a reduction in expenditure on consumer durables. ${ }^{89}$ In Germany, consumer spending continued to rise for a full year after the crash - principally because of rapid wage growth driven by very generous public sector pay awards. ${ }^{90}$ What the crash did influence was investment activity - the single most important determinant of variations in GDP during the late 1920s. ${ }^{91}$ If the stock market's artificial crash in 1927 mattered for the early German downturn, we need to find a link between the market's level and private sector investment.

Tobin first set out theoretical reasons why the ratio of the market's valuation of capital to the cost of acquiring new capital - Tobin's $q$ - should help to explain variations of investment over time. ${ }^{92}$ Typically, empirical studies show only a weak connection between investment and $q$ (either marginal or average). ${ }^{93}$ Barro's work on the US in the 1920s and 1980s, however, demonstrates that share prices themselves are better predictors of investment and output than Tobin's $q .{ }^{94}$ This is mainly because the calculated equity component of $q$ turns out to be a poor proxy for share prices. ${ }^{95}$ Using share prices, Barro finds that over the period

\footnotetext{
${ }^{84}$ Commercial and Financial Chronicle, 14.5.1927, p. 2835.

${ }^{85}$ Hardach 1976, Ritschl 1997, p. 88-90. Ritschl 1999, p. 4 argues for a larger impact on machinery investment.

${ }^{86}$ Balderston 1983. He later revised his position (Balderston 1993).

${ }^{87}$ Dominguez et al. 1988.

${ }^{88}$ Most studies show that wealth effects are very small. Cf. Poterba 2000.

${ }^{89}$ Mishkin 1978, Romer 1990.

90 James 1990.

91 Temin 1971, Temin 1976, p. 149-60.

92 Tobin 1969.

93 Summers 1981. Clark 1979.

94 Barro 1990, Barro 1989, Fama 1981.

${ }^{95}$ Barro 1990, p. 549.
} 
1921-89, share prices explain a significant proportion of the variation in investment. The collapse in share prices in 1929 can also explain an important part of the decline in US investment and GDP, 1930-32. Earlier work on modelling investment in interwar Germany has already addressed the issue of Tobin's $q$ and its predictive value for capital formation. Ritschl argues that investment reacted sensitively to changes in pseudo- $q .{ }^{96}$ We take this analysis further by implementing a Barro-style investment equation.

Stock Prices and Investment, 1925-39

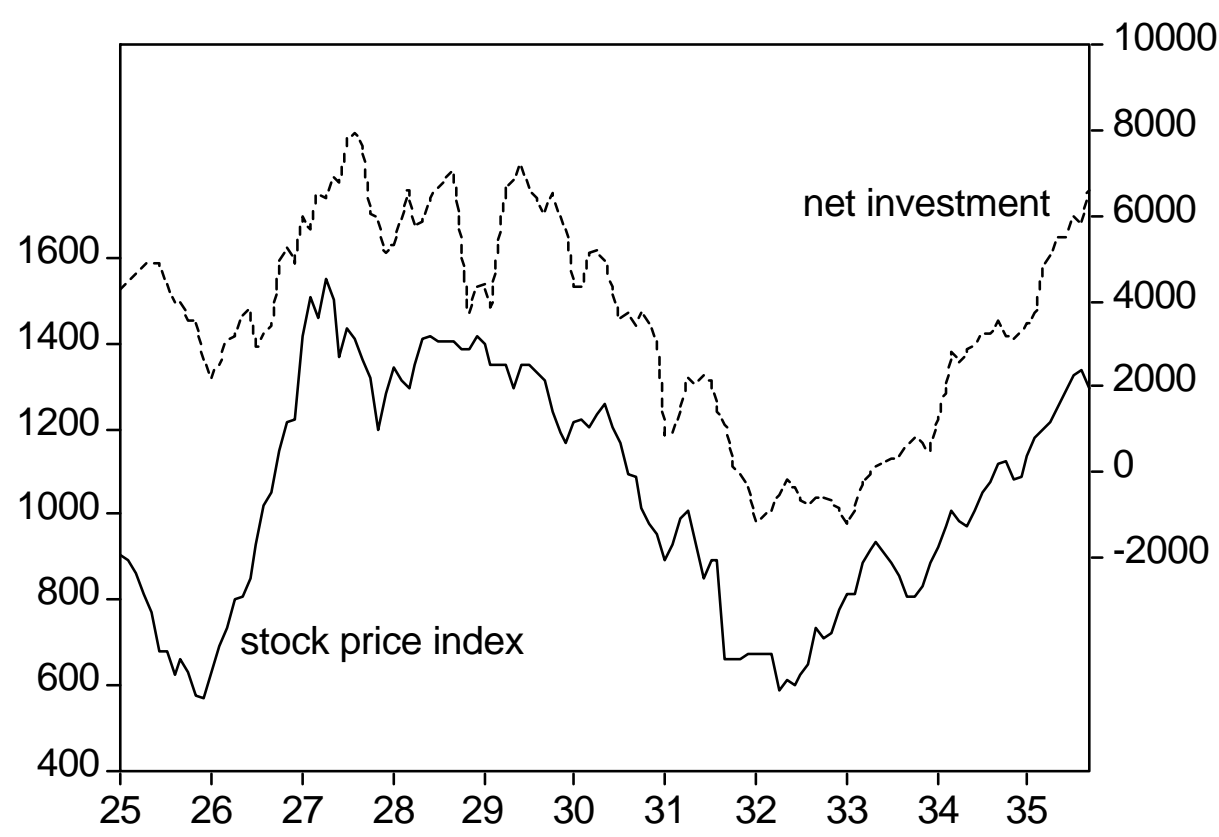

\section{Figure 6}

Figure 6 compares aggregate investment with the level of share prices in Germany, 19251935. ${ }^{97}$ Both series track each other closely. The sharp run-up in equity prices precedes the turning point of the investment series. Also the downward turning point is reached just a few months after the Reichsbank's intervention. Some brief episodes apart, both series begin their long decline in 1927, after Schacht's intervention. It is only after the stock market index has bottomed out in 1932, and after it began its recovery, that investment turns upwards. Grangercausality tests also clearly demonstrate that equity valuations mattered for investment - for the period $1 / 1925$ to $9 / 1935$, the standard F-test gives a statistic of 6.2 , equivalent to a

\footnotetext{
96 Ritschl 1994.

97 Investment is the net investment series in Ritschl (1997), interpolated by the output of investment goods according to Institut für Konjunkturforschung (1936).
} 
probability of only 2.5 percent that we cannot reject the null of no granger causality running from share prices to investment. The reverse, testing for investment causing share prices, yields a statistic of 0.24 , equivalent to a 78 percent probability.

We repeat Ritschl's estimation for the period at hand, again employing the Johansen technique. Following Barro, we use share prices directly. For the late 1920s, there is consistent evidence that share prices and investment in Weimar's economy are cointegrated (Table 5). ${ }^{98}$

Table 5: Johansen Test for Cointegration - Investment and Share Price Index

\begin{tabular}{|c|c|c|c|c|c|}
\hline & Eigenvalue & $\begin{array}{c}\text { Likelihood } \\
\text { ratio }\end{array}$ & $\begin{array}{l}5 \% \text { critical } \\
\text { value }\end{array}$ & $\begin{array}{c}1 \% \text { critic } \\
\text { value }\end{array}$ & $\begin{array}{l}\text { Hypothesis: No } \\
\text { of co vectors }\end{array}$ \\
\hline \multirow[t]{2}{*}{ 1/1925-9/1935 } & 0.02 & 2.54 & 12.5 & 16.3 & 0 \\
\hline & 0.0001 & 0.014 & 3.84 & 6.5 & 1 \\
\hline \multirow[t]{2}{*}{$1 / 1925-12 / 1929$} & 0.247 & 16.5 & 12.5 & 16.3 & $0 *$ \\
\hline & 0.000005 & 0.00299 & 3.84 & 6.5 & 1 \\
\hline \multirow[t]{2}{*}{$1 / 1925-12 / 1928$} & 0.32 & 18.2 & 12.5 & 16.3 & $0 *$ \\
\hline & 0.13 & 0.62 & 3.84 & 6.5 & 1 \\
\hline
\end{tabular}

Note: * indicates significance at the $5 \%$ level.

It is only when the sample period is extended beyond the onset of the Great Depression that this relationship begins to fall apart. For the period as a whole, investment and share price track each other quite closely, and the run-up in prices in 1926/27 appears more like a correction of a prior undervaluation than a period of irrational exuberance. The sharp correction induced by the curtailment of margin lending therefore caused investment spending to be lower than it otherwise would have been.

Before we can accept this conclusion, we need to consider a range of alternative explanations of investment performance. The most obvious variable to consider is the cost of capital, as proxied by interest rates. ${ }^{99}$ Also, work on irreversibility and investment in recent years suggests a link between uncertainty and capital formation. ${ }^{100}$ We use two alternative interest rates - the yield on gold-backed mortgage bonds and the monthly money rate. Also, possible uncertainty effects are included by calculating a rolling average of the magnitude of output

\footnotetext{
98 Pretesting established that the data series are not trended; also, we assumed no trend in the data generating process.

${ }_{99}$ Voth 1995 argues that high interest rates were crucial in holding down investment.
} 
changes, OutputV. In an alternative specification, we also try to capture uncertainty effects by including the volatility of share prices (StockV). Finally, we test for the possible effects of a profit squeeze by including an index of unit labour costs. Note that this variable can be interpreted as a proxy for cash-flow effects, or alternatively as an indicator of wage pressure and a Borchardt-style brake on investment. ${ }^{101}$ Table 6 shows estimates from an autoregressive distributed lag estimation procedure to obtain short- and long-run estimates. The optimum lag structure is chosen based on the Schwarz Bayesian Criterion. ${ }^{102}$

${ }^{100}$ Dixit and Pindyck 1994, Bernanke 1983.

101 There is an extensive literature arguing that investment is constrained by firm liquidity. Cf. Hoshi, Kashyap, and Sharfstein (1991), Elston (1998). There are however good theoretical reasons to doubt the validity of the approach on both theoretical and empirical grounds (Kaplan and Zingales 1997, Fohlin 1998).

102 We estimated with a maximum of six lags. The program then estimated all possible combinations (on average, more than 125 regressions). The one with the lag structure that resulted in the best SBC score was selected. All estimation was carried out in Microfit 4.0. 
Table 6: Determinants of Investment

\begin{tabular}{|c|c|c|c|c|c|c|c|c|}
\hline \multirow{19}{*}{$\begin{array}{l}\text { regression } \\
\text { ARDL } \\
\text { estimates }\end{array}$} & & 1 & 2 & 3 & 4 & 5 & 6 & 7 \\
\hline & $\operatorname{Inv}(-1)$ & $\begin{array}{l}0.71 * * \\
(9.02)\end{array}$ & $\begin{array}{c}0.69 * * \\
(9.1)\end{array}$ & $\begin{array}{c}0.79 * * \\
(6.5)\end{array}$ & $\begin{array}{c}0.67 * * \\
(7.1)\end{array}$ & $\begin{array}{l}0.7 * * \\
(9.5)\end{array}$ & $\begin{array}{l}0.71 * * \\
(9.7)\end{array}$ & \\
\hline & $\operatorname{Inv}(-2)$ & & & $\begin{array}{r}-0.29 \\
(2.4)\end{array}$ & & & & \\
\hline & Stock & $\begin{array}{c}2.4 * * \\
(3.2)\end{array}$ & $\begin{array}{l}1.8 * * \\
(3.7)\end{array}$ & $\begin{array}{l}2.7 * * \\
(4.8)\end{array}$ & $\begin{array}{l}2.1 * * \\
(3.4)\end{array}$ & $\begin{array}{l}1.4 * * \\
(3.4)\end{array}$ & & \\
\hline & $\ln$ (Stock) & & & & & & $\begin{array}{l}0.31 * * \\
(3.7)\end{array}$ & $\begin{array}{c}0.78 * * \\
(8.8)\end{array}$ \\
\hline & GoldR & $\begin{array}{c}225.5 \\
(1.2)\end{array}$ & & & & & & \\
\hline & MM & & & $\begin{array}{l}164.5 \\
(2.6)\end{array}$ & & & & \\
\hline & Unit & & $\begin{array}{c}6.5 \\
(0.2)\end{array}$ & & & & & \\
\hline & OutputV & & & & $\begin{array}{l}-0.14 \\
(0.02)\end{array}$ & & & \\
\hline & ShareV & $\begin{array}{l}12.2 * \\
(2.4)\end{array}$ & & $\begin{array}{c}8.7 \\
(1.8)\end{array}$ & & & & \\
\hline & $\mathrm{C}$ & $\begin{array}{c}-3279.2 \\
(1.6)\end{array}$ & $\begin{array}{l}-877.7 \\
(-0.26)\end{array}$ & $\begin{array}{c}-2230.5 * * \\
(2.9)\end{array}$ & $\begin{array}{c}-459.7 \\
(1.8)\end{array}$ & $\begin{array}{l}-257.7 \\
(0.7)\end{array}$ & $\begin{array}{c}0.23 \\
(0.48)\end{array}$ & $\begin{array}{c}2.98 * * \\
(4.8)\end{array}$ \\
\hline & $\operatorname{adj} . R^{2}$ & 0.83 & 0.84 & 0.86 & 0.83 & 0.82 & 0.84 & 0.52 \\
\hline & DW & 1.73 & 1.7 & 2.1 & 1.6 & 1.6 & 1.7 & 0.44 \\
\hline & SBC & -547.4 & -524.7 & -510 & -487.5 & -522.9 & 36.5 & 7.5 \\
\hline & LM & $\begin{array}{c}13.2 \\
(0.36)\end{array}$ & $\begin{array}{c}12.9 \\
(0.37)\end{array}$ & $\begin{array}{c}11.9 \\
(0.45)\end{array}$ & $\begin{array}{c}12.7 \\
(0.39)\end{array}$ & $\begin{array}{c}9.5 \\
(0.7)\end{array}$ & $\begin{array}{l}7.3 \\
(0.8)\end{array}$ & $\begin{array}{l}47.1 \\
(0.0)\end{array}$ \\
\hline & Ramsey & 0.3 & 0.17 & 0.5 & 0.27 & 0.76 & 0.75 & 5.7 \\
\hline & & (0.59) & $(0.9)$ & $(0.5)$ & $(0.6)$ & $(0.38)$ & $(0.4)$ & $(0.02)$ \\
\hline & Normality & $\begin{array}{c}3.5 \\
(0.18)\end{array}$ & $\begin{array}{c}5.3 \\
(0.07)\end{array}$ & $\begin{array}{c}3.3 \\
(0.19)\end{array}$ & $\begin{array}{c}4.6 \\
(0.1)\end{array}$ & $\begin{array}{c}4.03 \\
(0.13)\end{array}$ & $\begin{array}{c}5.7 \\
(0.06)\end{array}$ & $\begin{array}{c}3.7 \\
(0.15)\end{array}$ \\
\hline & $\begin{array}{l}\text { Hetero- } \\
\text { scedasticity }\end{array}$ & $\begin{array}{c}1.8 \\
(0.18)\end{array}$ & $\begin{array}{c}1.93 \\
(0.16)\end{array}$ & $\begin{array}{c}1.98 \\
(0.16)\end{array}$ & $\begin{array}{c}1.35 \\
(0.24)\end{array}$ & $\begin{array}{c}1.5 \\
(0.2)\end{array}$ & $\begin{array}{l}0.27 \\
(0.6)\end{array}$ & $\begin{array}{l}154.2 \\
(0.0)\end{array}$ \\
\hline \multirow[t]{8}{*}{$\begin{array}{l}\text { Long-run } \\
\text { coefficients } \\
\text { from ARDL }\end{array}$} & Stock & $\begin{array}{c}8.34 * * \\
(4.1)\end{array}$ & $\begin{array}{l}5.9 * * \\
(5.05)\end{array}$ & $\begin{array}{l}5.5 * * \\
(6.7)\end{array}$ & $\begin{array}{c}6.3 * * \\
(5.3)\end{array}$ & $\begin{array}{c}5.04 * * \\
(4.7)\end{array}$ & & \\
\hline & $\ln$ (Stock) & & & & & & $\begin{array}{l}1.09 * * \\
(4.9)\end{array}$ & \\
\hline & GoldR & $\begin{array}{l}751.1 \\
(1.2)\end{array}$ & & & & & & \\
\hline & MM & & & $\begin{array}{c}338.1 * * \\
(3.5)\end{array}$ & & & & \\
\hline & StockV & $\begin{array}{l}42.9 * \\
(2.1)\end{array}$ & & $\begin{array}{c}17.8 \\
(1.7)\end{array}$ & & & & \\
\hline & OutputV & & & & $\begin{array}{l}-0.42 \\
(0.2)\end{array}$ & & & \\
\hline & Unit & & $\begin{array}{c}21.6 \\
(0.19)\end{array}$ & & & & & \\
\hline & $\mathrm{C}$ & $\begin{array}{c}-11354.5 \\
(1.7)\end{array}$ & $\begin{array}{l}-2909 \\
(0.26)\end{array}$ & $\begin{array}{l}-4583 \\
(3.1)\end{array}$ & $\begin{array}{c}-1402.7 \\
(0.96)\end{array}$ & $\begin{array}{c}-917.9 \\
(0.7)\end{array}$ & $\begin{array}{c}0.8 \\
(0.5)\end{array}$ & \\
\hline
\end{tabular}

Note: $\quad *, * *$ indicate significance at the 5 and $1 \%$ level, respectively. T-statistics in parentheses. Dependent variable is investment. Estimation method ARDL. Stock is the performance index in Gielen (1991), GoldR and MM are the yield on gold-backed mortgage bonds and monthly interest rates, respectively, from Institut für Konjunkturforschung (1936), StockV and OutputV are the volatility during the preceding six months for stock prices and industrial output, calculated as the average squared percentage change per month, and Unit is the index of unit wage costs, as taken from Corbett (1991) and interpolated with the index of hourly wages for skilled workers. ${ }^{103}$ The LM-, Ramsey-, normality- and heteroscedasticity tests are given in the $\chi^{2}$ form. Probability levels are given in parentheses below the test statistics. Sample period is Jan. 1925 to Dec. 1930.

103 For 1925-27, the negotiated hourly wage of skilled workers in the highest age-group was taken from the German statistical yearbook 1930 (Statistisches Reichsamt 1930, p. 299). For the period 1928-30, the 
The coefficient on the interest rate variables is ambiguous. It is either wrongly signed or wrongly signed and insignificant. The share price volatility variable is also wrongly signed. Volatility of output has the right sign, but is insignificant (and has only a small impact). The variable that comes through most strongly and consistently is the share price index. These results are robust to changes in the sample period. ${ }^{104}$ We estimate a parsimonious specification to obtain reliable coefficients (regression 5). As the log specification demonstrates, an increase in the share price index by one percent leads approximately to one percent higher investment (regression 6). Use of OLS as an estimation technique does not substantially alter the result, though the poor diagnostics indicate that the use of cointegration techniques is necessary (regression 7). ${ }^{105}$

Why did the intervention have such strong effects in the stock market? By leaning on the banks, the Reichsbank effectively signalled it would intervene to bring share prices down to the levels it found acceptable. Many contemporary commentators were shocked by the strongarm tactics of the Reichsbank. ${ }^{106}$ Some spoke of a 'Reichsbank dictatorship', and of intervention reminiscent of centrally-planned economies. ${ }^{107}$ Even those that accepted the possibility of a bubble felt that the chosen instrument of intervention - the curtailing of margin lending - was much too blunt, and that higher margin requirements would have been more appropriate. ${ }^{108}$ The strong effects on the stock market itself are therefore largely the result of a wide-spread perception that the Reichsbank would cap capital gains with whatever means were necessary, including those that contemporaries perceived as unnecessarily brutal.

We also need to understand the strong knock-on effects on the economy and investment in the aggregate. In Barro's study, the results are insensitive to the inclusion of after-tax profits in

\footnotetext{
Statistisches Jahrbuch 1932 (Statistisches Reichsamt 1932, p. 273) was used. Since the number of industries covered increased from 12 to 17 in 1927, the series was spliced in January 1927 and adjusted accordingly. The nominal wage series thus obtained was used to calculate a real wage series, using PWHO as a deflator.

${ }^{104} \mathrm{Cf}$. Appendix 1. The only variable that, in addition to the stock price variable, is consistently significant in the extended sample is the unit labour cost proxy. This is arguably driven by the deflation after 1930 and the resulting rise in real wages during the depression, rather than any fundamental imbalance during the 1920s.

${ }^{105}$ Note that a proxy for profitability (unit labour cost) was also tried. We fail to find a strong and persistent effect. this is similar to other results in the literature (Voth 1995).

106 The Frankfurter Zeitung spoke of a "Höchstpreispolitik". Frankfurter Zeitung, 15.5.1927, Art. "Pferdekur Warum?".

${ }^{107}$ Frankfurter Zeitung, 13.5.1927; Frankfurter Zeitung, 15.5.1927, Art. "Pferdekur - Warum?”: “Es handelt sich um einen beispiellosen Reglementierungsversuch, um eine planwirtschaftlichen Aktion ersten Ranges... "

${ }^{108}$ Frankfurter Zeitung, 15.5.1927, Art. "Pferdekur - Warum?".
} 
the estimation equation, making it unlikely that the stock market variables merely proxy for cash-flow effects. Our own proxy for profitability failed to reduce the significance of the stock market variable. If we are to heed Temin's advice to consider the role of expectations more seriously, we need to find an event that would have caused a downturn in business sentiment. ${ }^{109}$ At the simplest level, we can argue that the level of the stock market was perceived as a direct indicator of economic health - the very reason why Schacht felt that high equity values undermined Germany's case for a revision of the Dawes Plan. As his prominent critic Adolf Weber put it after the intervention: 'The public judges economic conditions according to the quotations for shares published daily in the newspapers. It believes that the sad numbers - that 'delight' the readers of newspapers for months now - demonstrate the bad state of our [the German] economy.' 110 The collapse in share prices is an highly plausible candidate for the increasing pessimism in Germany's business community, adding to the effects of a continuing profit squeeze emphasized by earlier authors. ${ }^{111}$

In addition to 'animal spirits', two other factors can be cited that can help us to understand why the stock market rout led to an investment and business downturn - the weakening of firm balance sheets and lower stock market liquidity. Recent literature on the Great Depression has highlighted the importance of the cost of credit intermediation. ${ }^{112}$ Negative shocks to household and firm wealth will weaken balance sheets. In the presence of asymmetric information, lending becomes more risky for banks, and can lead to a reduction in credit. This may in turn aggravate the slump. ${ }^{113}$ A downturn in business conditions can thus be amplified by changes in the agency cost of lending - the 'financial accelerator' ${ }^{114}$ For the US, Bernanke shows how bank failures and panics drove up the cost of intermediation. ${ }^{115}$ In an international perspective, Bernanke and James argue that debt-deflation effects were important in reducing the effectiveness of financial intermediation, aggravating the Great Depression. $^{116}$

\footnotetext{
${ }^{109}$ As Temin (1989, p. 104) put it: "Modern theories of the economy have brought expectations onto the stage as a lead actor, unlike its earlier position as extra or understudy. Our historical accoutns nned to follow suit."

${ }^{110}$ Weber 1928, p. 12.

111 Balderston 1992, James 1990, Borchardt 1991.

112 Bernanke and James 1991, Eichengreen and Grossman 1994.

113 Mishkin 1991.

114 Bernanke, Gertler, and Gilchrist 1996.

115 Bernanke 1983; Temin (1989) finds that the cross-sectional evidence does not support the Bernanke hypothesis.

116 Bernanke and James 1991.
} 
Declines in the value of a firms assets as a result of a stock market crash will lower the value of collateral it can offer. This in itself may cause greater asymmetric information problems, causing a rise in long-term interest rates for private firms and a fall in investment. ${ }^{117}$ This problem is aggravated if the stock market slump causes a reduction in new equity issuance. Since banks will not accept debt/equity ratios above a certain limit, they will be more reluctant to lend, thus reducing opportunities to raise external financing still further. Just as the anonymous businessman cited by the Associated Press had predicted, the floatation of new shares on German stock exchanges was reduced sharply by Schacht's intervention. It peaked in the second quarter of 1927, at the time of the market high before the intervention (Figure 7). Despite a brief rebound in the third quarter of 1928, it would not recover preintervention levels before the post-war period.

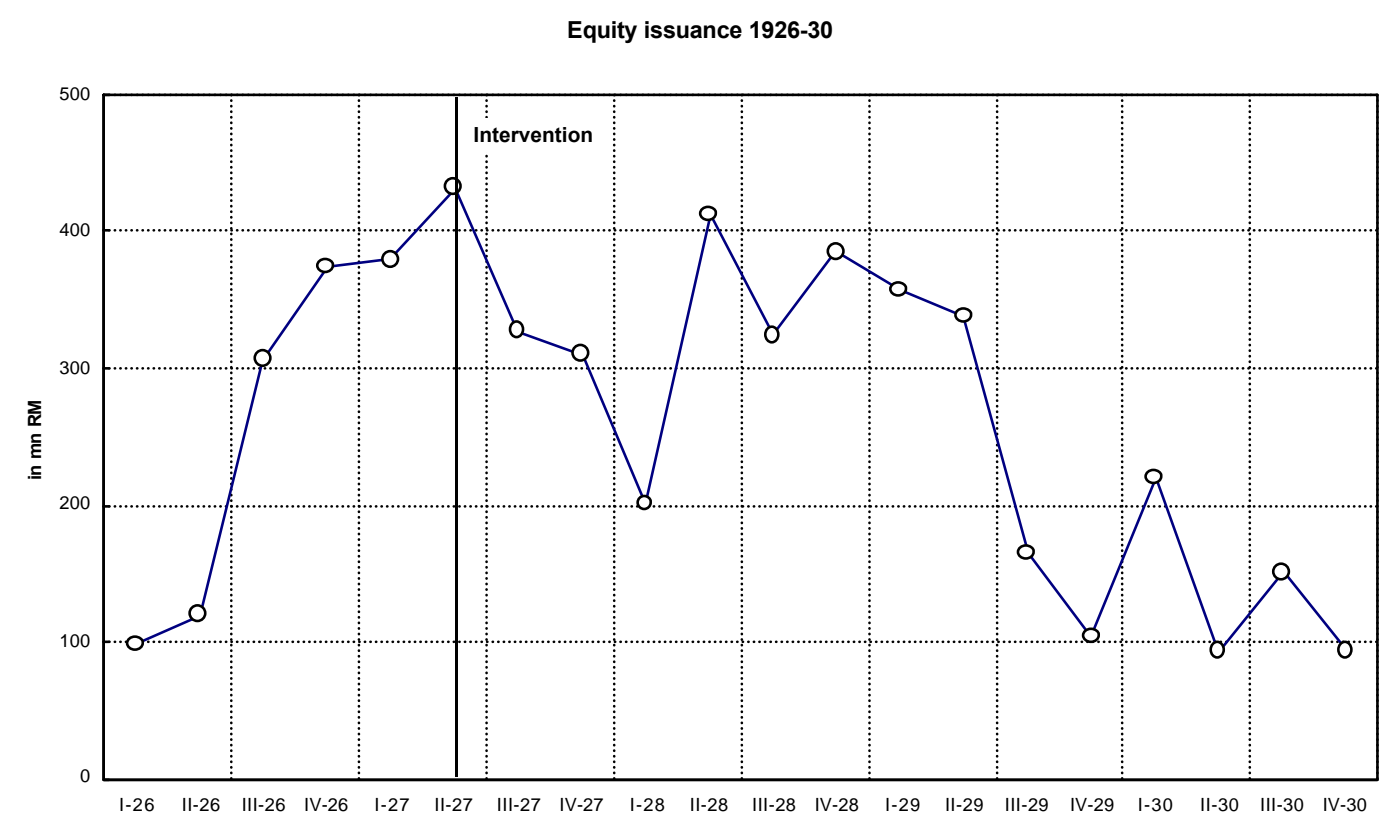

\section{Figure 7}

In the German situation during the interwar period, there is every reason to expect particularly drastic effects from financial accelerator effects. Banks' capital ratios were low after the hyperinflation. More importantly, the universal bank system meant that many banks held equity stakes in companies that borrowed from them. Not only would the value of collateral offered by firms therefore be hit by a stock market crash - the banks' own equity base would

${ }^{117}$ Calomiris and Hubbard 1990, Greenwald and Stiglitz 1988. 
be adversely affected. The rapid collapse in lending after 1928 may well have been driven in part by the events on the stock exchange.

One other consequence also strongly suggests that the investment slowdown following the Reichsbank intervention in 1927 was caused by the stock market crash. Trading volume on the exchanges fell sharply. Direct figures are not available, but the revenues from stamp duty indicate the orders of magnitude involved. From an average of $9.55 \mathrm{mn}$ RM per month in March-May, revenues fell to $5.17 \mathrm{mn}$ during the rest of the year. The collapse in trading volume made German shares less liquid - transaction costs rose significantly. Consequently, the stock market's role in allocating capital became more difficult. In a series of studies, the World Bank has recently argued that stock market liquidity has an important influence on subsequent growth. ${ }^{118}$ In a cross-section of 47 economies, Levine and Zervos found that for every reduction in the value of stock market turnover relative to GDP by ten percentage points, growth during the period $1976-92$ suffered by 0.9 percent p.a. ${ }^{119}$

How important was the correction in economic terms? Using the long-run coefficients from the parsimonious ARDL-specification (regression 6, Table 6), we can calculate a counterfactual of investment performance had Schacht abstained from his pre-emptive strike. If share prices had carried on rising at a moderate rate of two percent p.a., then they would have been some 12 percent higher than their actual values at the end of $1928 .{ }^{120}$ Investment would have been some 13 percent higher than in May 1927. Compared to the actual level for the year 1928 as a whole, it would have been 11.5 percent higher. By December 1929, the 'penalty' would have widened to 16 percent. Much of the 'investment shortfall' that some authors have claimed to have found in interwar Germany, if it did exist, may well be the result of the central bank's attempt to force down share prices. ${ }^{121}$

\footnotetext{
${ }^{118}$ Levine 1997.

${ }^{119}$ Levine and Zervos 1998. Calculating the impact of the stock market intervention via the liquidity channel is not possible, as we lack direct figures on the value of turnover.

${ }_{120}$ Since share prices would have risen less than dividends, the dividend yield could have recovered.

121 Spoerer (1997) and Voth (1993) present evidence that investment in interwar Germany was not lower than during the Empire. For a view to the contrary, Borchardt 1991.
} 


\section{CONCLUSION: A ‘SOFT LANDING’ GONE WRONG}

This paper analysed the German stock market bust of 1927, when the German central bank intervened indirectly to lower the level of share prices. Much of the literature has interpreted Schacht's intervention primarily in the context of foreign capital flows. In Germany, monetary policy was constrained by gold standard rules. Massive capital flows under fixed exchange rates can - as the Reichsbank argued - easily have destabilizing consequences. ${ }^{122}$ In the context of foreign borrowing, the attack on the stock market was nonetheless an unmitigated disaster since it failed to stem the inflow of foreign funds and did not help to ease conditions in the money market. This paper has argued that concern about the stock market was not a mere auxiliary to worries about foreign loans. Instead, Schacht and the Reichsbank were directly concerned about overvaluation in the market, and believed that a crash would be the "best thing that could happen to the German people".

Without raising interest rates sharply as such, it was one of the more effective interventions carried out by a central bank. On May 13, the share index compiled by the Reichskreditanstalt closed 22 percent below its level on May 3, and 11 percent down on the day. ${ }^{123}$ By November, despite temporary recoveries, the index was still down by one quarter, never to recover pre-intervention levels before the Great Depression had run its course. ${ }^{124}$ In assessing the benefits and dangers of this move, we first examined if there is evidence of a bubble developing in the German market. The conclusion from cointegration analysis, an examination of the time-series properties of the data, and a dividend yield model was that the rapid run-up in prices prior to Schacht's intervention was not caused by "irrational exuberance". Instead, lower interest rates and a wider normalization of economic conditions after the end of hyperinflation were responsible. Compared to other markets recovering from traumatic events (such as a hyperinflation), asset price increases in Germany were not particularly steep.

Pricking a non-existing bubble had significant economic consequences. Far from the 'blessing' that Reichsbank President Schacht expected it to be, it had strong adverse

\footnotetext{
122 Krugman 1999.

123 Benning 1929, p. 147and Beer 1999, p. 204.

124 Gielen 1992; Balderston 1983, p. 414-5. The price of some stocks suffered by as much as $40 \%$. Cf. Benning 1929, p. 161.
} 
consequences. ${ }^{125}$ Weimar's only investment boom quickly came to an end, and the economy's downturn was in part caused by Schacht's ill-considered intervention in the equity market. Our analysis thus lends indirect support to Temin's argument about the onset of the Great Depression in Germany. The timing of changes in international capital flows does not suggest that they played a crucial role in tipping the economy into recession in 1927/28. Instead, domestic reasons for the downturn need be sought. ${ }^{126}$ In addition to a surge in pessimism because of continued low profits, as suggested by Balderston, James and Borchardt, this paper argues that there were other important reasons why business sentiment turned sour in 1927/28. The stock market crash is precisely the kind of domestic event that could - as suggested by Temin - have led to a sharp decline in business sentiment, reinforcing the effects of continuing low profitability.

We also argued that the destruction of equity value - by lowering the value of collateral, of some of the banks' own equity holdings, and by sharply reducing public offerings - increased the costs of financial intermediation. This contributed and substantially aggravated the early downturn in Germany. Via the 'financial accelerator' mechanism, the stock market crash probably was instrumental for the reduction in credit and the curtailment of business investment. Both GDP and capital stock could have been markedly higher had it not been for the Reichsbank's intervention Germany in the 1920s was, in relative terms, much larger an economic power than it is today - the world's second-largest economy. On a speculative note, one might therefore add that the early German downturn, and the consequences it had for her trading partners, did nothing to stabilize the world economy prior to the outbreak of the Great Depression. ${ }^{127}$ As an observer of the Federal Reserve Bank of New York put it in the summer of 1927: “. . the whole episode was a blunder.",128

Should asset bubbles be pricked? Rapid increases in asset prices present central banks with a dilemma. Simulation studies of monetary policy find that an explicit targeting of asset prices - over and above their effect on the price level - may amplify 'boom-bust' cycles. ${ }^{129}$ If there

\footnotetext{
${ }^{125}$ Schacht said that “... this level of share prices will under all circumstances collapse and that nothing better could happen to us than that it collapses... " Abramowski 1988, p. 608.

126 Temin 1971; Temin 1976, p. 248.

${ }^{127}$ Ritschl (1999) has examined the extent to which the downturn in Germany was predictable. In contrast to the findings by Dominguez et al. (1987), he finds that most of the decline in output from 1927 onwards was predictable.

${ }_{128}$ Hardach 1976, p. 80f.

129 Bernanke and Gertler 1999.
} 
is a danger of price increases spilling over into the rest of the economy, it may appear sensible to 'step on the brakes' and deflate what appears to be a bubble. At the same time, active intervention in asset markets, and deliberate attempts to change prices, may be as dangerous as other forms of tinkering with the price mechanism. Distortions in relative prices may cause misallocation of resources, and perhaps more importantly, growth and investment can suffer if the central bank decides to intervene at an inappropriate time.

Three policy lessons appear to emerge from Germany's 'Black Friday'. First, distinguishing bubbles from increases in asset prices driven by fundamentals (or sensible beliefs about the future development of fundamentals) is no easy matter. Despite applying relatively sophisticated valuation analysis based on long-run comparisons of the German data, the Reichsbank appears to have attacked a non-existing "Spekulationsblase". ${ }^{130}$ Even with more advanced recent techniques, the bias tends to be in favour of finding a bubble where there is none. ${ }^{131}$ Given that monetary policy has to operate under this veil of uncertainty, central banks may be well-advised to only intervene when there is overwhelming evidence of "irrational exuberance".

Second, a differential approach that targets speculators directly (by restricting brokers loans etc.), is no more likely to avoid negative consequences for the economy as a whole than a more aggressive tightening of overall monetary policy. The unforeseen severity of the crash implies that fine-tuning can be hard to achieve. The similarities in the cases of Japan in 1989, the US in 1929, and Germany in 1927 suggest that balance sheet effects may have been crucial in transmitting the effects of asset prices to the economy as whole. ${ }^{132}$ Effective counter-cyclical policy would then imply that policy has to become expansionary very rapidly once the stock market 'bubble' had been deflated.

Third, the difficulty of predicting the potentially grave repercussions of deflating 'bubbles' should be taken into account when appraising the apparent dangers of asset price inflation. On balance, there appears to be good reason to apply the most stringent standards before rapidly rising share prices can call for central bank intervention. Only if spill-over effects threaten price stability in the economy as a whole is intervention likely to be justified. The details of

\footnotetext{
${ }^{130}$ Schacht in his speech in Stralsund, Stralsunder Tageblatt, 27.5.1927.

${ }^{131}$ Hamilton 1987, Hamilton and Whiteman 1985.

132 Bernanke and Gertler 1999.
} 
the Reichsbank intervention in 1927 also cast an interesting light on the issue of central bank intervention in general. In the case of exchange rates, the general belief is that central banks should stand aside (unless conditions are extreme) because they are not powerful enough visà-vis market players. In contrast, stock market interventions by central banks appear to be 'too successful'. Since neither the extent of the market's fall brought about by specific measures nor the amount of 'collateral damage' in the rest of economy can be controlled or anticipated accurately, it may be best not to intervene at all. 


\section{References}

Abramowski, G., (1988), Akten der Reichskanzlei. Die Kabinette Marx III und IV, Boppard am Rhein.

Angell, J. (1929), The Recovery of Germany, New York.

Balderston, T. (1993), The Origins and Course of the German Economic Crisis, Berlin.

Balderston, T. (1977), 'The German Business Cycle in the 1920s: A Comment', Economic History Review 30.

Balderston, T. (1983), 'The Beginning of the Depression in Germany, 1927-30: Investment and the Capital Market', Economic History Review 36.

Barro, R. (1990), 'The Stock Market and Investment', Review of Financial Studies 3.

Barro, R. (1989), 'The Stock Market and the Macroeconomy: Implications of the October 1987 Crash', in R. Kamphuis et al., eds., Black Monday and the Future of Financial Markets, Homewood, Ill.

Beer, J. (1998), Der Funktionswandel der deutschen Wertpapierbörsen in der Zwischenkriegszeit (1924-1939), Frankfurt.

Benning, B. (1929), 'Der "Schwarze Freitag". Eine Untersuchung des Börseneingriffs vom 13. Mai 1927', in: A. Weber, ed., Effektenbörse und Volkswirtschaft, Jena.

Bernanke, B. and M. Gertler (1999), 'Monetary Policy and Asset Price Volatility', paper presented at the Federal Reserve Bank of Kansas City conference, Jackson Hole, Wyoming, August 26-28.

Bernanke, B. (1983), 'Irreversibility, Uncertainty, and Cyclical Investment', Quarterly Journal of Eocnomics 98, pp. 85-106.

Bernanke, B. and H. James (1991), 'The Gold Standard, Deflation, and Financial Crisis in the Great Depression: An International Comparison', in: G. Hubbard, ed., Financial Markets and Financial Crisis, Chicago.

Bernanke, B. (1983), 'Nonmonetary Effects of the Financial Crisis in the Propagation of the Great Depression', American Economic Review 73, pp. 257-76.

Bernanke, B., M. Gertler, and S. Gilchrist (1996), 'The Financial Accelerator and the Flight to Quality', Review of Economics and Statistics 78, pp. 1-15.

Bittlingmayer, G. (1998), 'Output, Stock Volatility, and Political Uncertainty in a Natural Experiment: Germany 1880-1940', Journal of Finance 53.

Borchardt, K. (1991), 'Economic Causes of the Collapse of the Weimar Republic', in Knut Borchardt (ed.), Perspectives on Modern German Economic History and Policy, Cambridge.

(1982), 'Zwangslagen und Handlungsspielräume in der großen Wirtschaftskrise der frühen dreißiger Jahre', in: ibid., ed., Wachstum, Krisen, Handlungsspielräume der Wirtschaftspolitik, Göttingen.

Calomiris, C. and G. Hubbard (1990), 'Firm Heterogeneity, Internal Finance, and "Credit Rationing", Economic Journal 100, pp. 90-104.

Campbell, J. and R. Shiller (1987), 'Cointegration and Tests of Present Value Relationships', Journal of Political Economy 95.

and P. Perron (1991), 'Pitfalls and Opportunities: What Macroeconomists Should Know about Unit Roots', in: O. Blanchard, S. Fischer, NBER Macroeconomics Annual, Cambridge and London. 
Choi, I. and B. Chung (1995), 'Sampling Frequency and the Power of Tests for a Unit Root: A Simulation Study', Economic Letters 49, pp. 131-36.

Corbett, David. Unemployment in Interwar Germany. Ph.D. diss., Harvard University, 1991.

Craine, R. (1993), 'Rational Bubbles: A Test', Journal of Economic Dynamics and Control 17.

DeLong, B. and M. Becht (1992), "'Excess Volatility" and the German Stock Market, 18761990', NBER working paper No. 4054.

Deutsche Bundesbank (1976), Deutsches Geld- und Bankwesen in Zahlen 1876-1975, Frankfurt.

Diba, B. and H. Grossman (1988), 'Explosive Rational Bubbles in Stock Prices?', American Economic Review 78.

Dixit, A. and R. Pindyck (1994), Investment under Uncertainty, Princeton.

Dominguez, K., R. Fair and M. Shapiro (1988), 'Forecasting the Depression: Harvard versus Yale', American Economic Review 78.

Eichengreen, B., Golden Fetters: The Gold Standard and the Great Depression 1919 - 1939, Oxford.

and J. Sachs (1985), 'Exchange Rates and Economic Recovery in the 1930s', Journal of Economic History 45.

and R. Grossman (1997), 'Debt Deflation and Financial Instability: Two Historical Explorations', in: F. Capie, G. Wood, eds., Debt Deflation in Theory and History, Houndmills.

Elston, J. (1998), 'Investment, Liquidity Constraints and Bank Relationships: Evidence from German Manufacturing Firms', in: Competition and Convergence in Financial Markets, Amsterdam.

Falkus, M. (1973), 'The German Business Cycle in the 1920s', Economic History Review 28.

Fama, E. and W. Schwert (1977), 'Asset Returns and Inflation', Journal of Financial Economics 5.

Flood, R. and N. Marion (1999), 'Perspectives on the Recent Currency Crisis Literature', International Journal of Finance and Economics 4.

Friedman, M. and A. Schwarz (1963), A Monetary History of the United States, 1867-1960, Princeton.

Froot, K. and M. Obstfeld (1991), 'Intrinsic Bubbles: The Case of Stock Prices', American Economic Review 81, pp. 1189-1214.

Gielen, G. (1994), Können Aktienkurse noch steigen?, Wiesbaden.

Goetzmann, W. and P. Jorion (1999), 'Global Stock Markets in the Twentieth Century', Journal of Finance 54, pp. 953-80.

(1999b), 'Re-emerging Markets', Journal of Financial and Quantitative Analysis 34, pp. $1-32$.

Gordon, M. (1962), The Investment, Financing and Valuation of the Corporation, Homewood, Ill.

Greenwald, B. and J. Stiglitz (1988), 'Information, Finance Constraints, and Business Fluctuations', in M. Kahn and S. Tsiang, ed., Expectations and Macroeconomics, Oxford.

Hamilton, J. (1986), 'On Testing for Self-fulfilling Speculative Price Bubbles', International Economic Review 27. 
and C. Whiteman, 'The Observable Implications of Self-Fulfilling Expectations', Journal of Monetary Economics 16 (1985).

Hardach, G. (1976), Weltmarktorientierung und relative Stagnation, Berlin.

Hoffmann, W. (1965), Das Wachstum der deutschen Wirtschaft, Berlin.

Holtfrerich, C.-L. (1990), 'Economic Policy Options and the End of the Weimar Republic', in: Ian Kershaw, ed., Weimar: Why Did German Democracy Fail?, New York.

(1984), 'Zu hohe Löhne in der Weimarer Republik? Bemerkungen zur Borchardt-These', Geschichte und Gesellschaft 10.

Hooker, M. (1992), 'Testing for Cointegration: Power versus Frequency of Observation', Economic Letters 41, pp. 359-62.

Hoshi, T., Kashyap, A. and D. Sharfstein (1991), 'Corporate Structure, Liquidity, and Investment', Quarterly Journal of Economics 106, pp. 33-60.

Institut für Konjunkturforschung (1936), Konjunkturstatistisches Handbuch, Hamburg: Hanseatische Verlagsanstalt.

James, H. (1986), The German Slump: Politics and Economics 1924-1936, Oxford.

(1985), The Reichsbank and Public Finance in Germany 1924-1933, Frankfurt a.M.

(1990), 'Economic Reasons for the Collapse of the Weimar Republic', in: I. Kershaw, ed., Weimar: Why Did German Democracy Fail?, London.

Jorion, P., and W. Goetzmann, 'Global Stock Markets in the Twentieth Century', Journal of Finance 54 (1999).

Kaplan, S. and L. Zingales, 'Do Investment-Cash-Flow Sensitivities Provide Useful Measures of Financing Constraints?', Q uarterly Journal of Economics 112, pp. 168-215.

King, S. (1999), 'Bubble Trouble', HSBC Global Economics Research Paper.

Kindleberger, Ch. (1987), Article 'Bubbles', in: P. Newman et al., ed., New Palgrave. Dictionary of Economics, Houndsmills.

Krugman, P. (1999), 'Should the Fed Care about Stock Bubbles?', Fortune March 1.

(1999b), 'Balance Sheets, the Transfer Problem, and Financial Crises', International Tax and Public Finance 6.

Levine, R. (1997), 'Financial Development and Economic Growth: Views and Agenda', Journal of Economic Literature 35, pp. 688-726.

and S. Zervos (1998), 'Stock Markets, Banks, and Economic Growth', American Economic Review 88, pp. 537-58.

Maddison, A. (1995), Monitoring the World Economy, Paris.

Mishkin, F. (1987), 'The Household Balance Sheet and the Great Depression', Journal of Economic History 37.

(1991), Asymmetric Information and Financial Crises', in: G. Hubbard, ed., Financial Markets and Financial Crises, Chicago, pp. 69-108.

Müller, H. (1973), Die Zentralbank - eine Nebenregierung, Opladen.

Poterba, J. (2000), 'Stock Market Wealth and Consumption', Journal of Economic Perspectives 14.

Rappoport, P. and E. White (1993), 'Was There a Bubble in the 1929 Stock Market?', Journal of Economic History 53.

Romer, C., 'The Great Crash and the Onset of the Great Depression', Quarterly Journal of Economics 105. 
Ritschl, A. (1997), Deutschlands Krise und Konjunktur 1924-1934, Habilitationsschrift, Economics Department, Munich.

(1990), 'Zu hohe Löhne in der Weimarer Republik? Eine Auseinandersetzung mit Holtfrerichs Berechnungen zur Lohnposition der Arbeitsschaft 1925-1932', Geschichte und Gesellschaft 16, pp. 375-402.

(1999), 'Peter Temin and the Onset of the Great Depression in Germany: A Reappraisal', unpublished manuscript, Economics Department, Pompeu Fabra.

(1994), 'Goldene Jahre? Zu den Investitionen in der Weimarer Republik', Zeitschrift für Wirtschafts- und Sozialwissenschaften 114.

Schuker, S. (1988), American "Reparations" to Germany 1919-1933, Princeton.

Shiller, R. (1981), 'Do Stock Prices Move Too Much to be Justified by Subsequent Changes in Dividends?', American Economic Review 71.

Schröder, S. (1993), Steuerlastgestaltung der Aktiengesellschaften und Veranlagung zur Körperschaftssteuer im Deutschen Reich und den USA von 1918-1936, Ph.D. thesis, Economics Department, Free University, Berlin.

Spoerer, M. (1996), Von Scheingewinnen zum Rüstungsboom, Stuttgart.

(1997), 'Weimar's Investment Record in Intertemporal and International Perspective', European Review of Economic History 1.

Statistisches Reichsamt (1930), Statistisches Jahrbuch für das Deutsche Reich 1930, Berlin. (1932), Statistisches Jahrbuch für das Deutsche Reich 1932, Berlin.

Summers, L. (1981), 'Taxation and Corporate Investment: A q-Theory Approach', Brookings Papers on Economic Activity 1.

Taylor, J. (1993), 'Discretion vs. Policy Rules in Practice', Carnegie-Rochester Conference Series on Public Policy 39.

Temin, P. (1971), 'The Beginning of the Great Depression in Germany', Economic History Review 24. (1976), Did Monetary Forces Cause the Great Depression?, New York.

(1989), Lessons from the Great Depression, Cambridge, MA.

Voth, H.-J. (1995), 'Did High Wages or High Interest Rates Bring Down the Weimar Republic?', Journal of Economic History 55.

(1993), 'Wages, Investment and the Fate of the Weimar Republic: A Long-Term Perspective', German History 11.

White, E. (1990), 'The Stock Market Boom and Crash of 1929 Revisited', Journal of Economic Perspectives 4.

Weber, A. (1928), Hat Schacht recht? Die Abhängigkeit der deutschen Wirtschaft vom Ausland, Munich. 


\begin{tabular}{|c|c|c|c|c|c|}
\hline \multicolumn{2}{|c|}{$\begin{array}{l}\text { regression } \\
\text { estimation method } \\
\quad \text { exogenous variables }\end{array}$} & $\begin{array}{c}1 \\
\text { ARDL }\end{array}$ & $\begin{array}{c}2 \\
\text { ARDL }\end{array}$ & $\begin{array}{c}3 \\
\text { ARDL }\end{array}$ & $\begin{array}{c}4 \\
\text { ARDL }\end{array}$ \\
\hline \multirow[t]{18}{*}{$\begin{array}{l}\text { ARDL } \\
\text { estimates }\end{array}$} & $\operatorname{Inv}(-1)$ & $\begin{array}{l}0.89 * * \\
(22.7)\end{array}$ & $\begin{array}{l}0.86^{* *} \\
(24.9)\end{array}$ & $\begin{array}{l}0.74 * * \\
(16.3)\end{array}$ & $\begin{array}{l}0.8^{* *} \\
(15.9)\end{array}$ \\
\hline & $\operatorname{Inv}(-2)$ & & & & \\
\hline & Stock & $\begin{array}{l}1.3^{* * *} \\
(3.4)\end{array}$ & $\begin{array}{c}1.05^{* *} \\
(2.7)\end{array}$ & $\begin{array}{l}2.03 * * \\
(5.77)\end{array}$ & $\begin{array}{l}1.83 * * \\
(4.25)\end{array}$ \\
\hline & GoldR & & $\begin{array}{c}-168.1^{*} \\
(2.5)\end{array}$ & & \\
\hline & MM & $\begin{array}{l}-56.5 \\
(1.89)\end{array}$ & & & \\
\hline & Unit & & & $\begin{array}{c}-44.5^{* * *} \\
(4.0)\end{array}$ & \\
\hline & OutputV & & & & $\begin{array}{c}-13.02^{*} \\
(-2.3)\end{array}$ \\
\hline & OutputV(-1) & & & & $\begin{array}{c}15.8 * * \\
(2.8)\end{array}$ \\
\hline & ShareV & $\begin{array}{c}3.4 \\
(1.2)\end{array}$ & $\begin{array}{c}2.6 \\
(0.9)\end{array}$ & & \\
\hline & C & $\begin{array}{l}-655.4 \\
(1.57)\end{array}$ & $\begin{array}{c}496.4 \\
(0.7)\end{array}$ & $\begin{array}{c}3844.3^{* *} \\
(3.2)\end{array}$ & $\begin{array}{c}-1243^{* *} \\
(3.8)\end{array}$ \\
\hline & adj. $R^{2}$ & 0.95 & 0.95 & 0.96 & 0.95 \\
\hline & DW & 1.7 & 1.7 & 1.7 & 1.56 \\
\hline & SBC & -961.7 & -960.3 & -955.3 & -923 \\
\hline & $\mathrm{LM}$ & $\begin{array}{c}16.7 \\
(0.16)\end{array}$ & $\begin{array}{c}18.2 \\
(0.11)\end{array}$ & $\begin{array}{c}17.6 \\
(0.13)\end{array}$ & $\begin{array}{c}17.7 \\
(0.126)\end{array}$ \\
\hline & Ramsey & $\begin{array}{c}2.3 \\
(0.13)\end{array}$ & $\begin{array}{c}1.8 \\
(0.17)\end{array}$ & $\begin{array}{c}1.8 \\
(0.175)\end{array}$ & $\begin{array}{c}4.85 \\
(0.28)\end{array}$ \\
\hline & Normality & 30.02 & 32.9 & 34.7 & 7.7 \\
\hline & & $(0.0)$ & $(0.0)$ & $(0.0)$ & $(0.22)$ \\
\hline & $\begin{array}{l}\text { Hetero- } \\
\text { scedasticity }\end{array}$ & $\begin{array}{c}4.01 \\
(0.045)\end{array}$ & $\begin{array}{c}3.7 \\
(0.05)\end{array}$ & $\begin{array}{c}6.4 \\
(0.11)\end{array}$ & $\begin{array}{c}3.04 \\
(0.08)\end{array}$ \\
\hline \multirow{8}{*}{$\begin{array}{l}\text { Long-run } \\
\text { coefficients } \\
\text { from ARDL }\end{array}$} & Stock & $\begin{array}{c}11.23 * * \\
(4.9)\end{array}$ & $\begin{array}{l}7.7 * * \\
(4.08)\end{array}$ & $\begin{array}{l}7.9 * * \\
(10.8)\end{array}$ & $\begin{array}{l}9.4^{* *} \\
(8.23)\end{array}$ \\
\hline & ln (Stock) & & & & \\
\hline & GoldR & & $\begin{array}{c}-1222.8 \\
(2.02)\end{array}$ & & \\
\hline & MM & $\begin{array}{c}-492.7 \\
(1.3)\end{array}$ & & & \\
\hline & StockV & $\begin{array}{c}29.7 \\
(1.15)\end{array}$ & $\begin{array}{l}18.76 \\
(1.02)\end{array}$ & & \\
\hline & OutputV & & & & $\begin{array}{c}14.4 \\
(0.64)\end{array}$ \\
\hline & Unit & & & $\begin{array}{c}-172.8^{* *} \\
(4.4)\end{array}$ & \\
\hline & $\mathrm{C}$ & $\begin{array}{c}-5718^{*} \\
(2.1)\end{array}$ & $\begin{array}{c}3611.0 \\
(0.64) \\
\end{array}$ & $\begin{array}{c}14934.9 * * \\
(3.5)\end{array}$ & $\begin{array}{c}-6361 * * \\
(0.7) \\
\end{array}$ \\
\hline
\end{tabular}

